マイクロ波反射法によるプラズマの密度測定

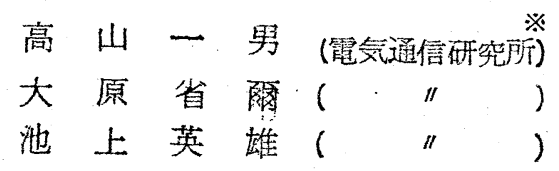

あらまし

マイクロ波によつてプラズマ密度を測定する目的で尊波管内に放電管を擩入し反射倞数を測定 した。これと同時に導波管内にプラズマ柱のもる場合の屋射係数と密度の関係を密度分布を考慮 して電磁界方程式から導い:。この間の一致は10\% 以内で充分に満足すべきものである。更に 探針に上つて密度測定を行い、実験誤差の範固内でマイクロ波で測定したものと一致する結界を得 た。

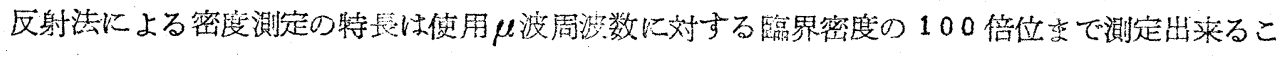

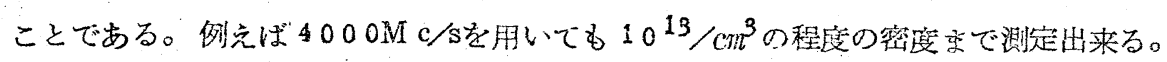

$\left(4000 \mathrm{M} / \mathrm{s} \mu\right.$ 波汶方方臨界密度は $\left.1.9 \times 10^{11} / \mathrm{cm}^{3}\right)$

まえがき

電離層による電磁波の区射と透過から電子密度を求めているように、古くからブラズマに対す る電䂭没の伝播特性からプラズマの常数を求めることが行われていた。ところが人工衙星と人工 惑星の出現によつて、ブラズマ中の伝播に関係するSeddon 法(1)やFaraday 効果を用いた 方法(2)によつて宇宙空間の電子密度が測定されるようになつた。かし、電酳波によるプラズマ の娜定が重視されるようになつた最大の原因は、約 10 年以前から開始された熱核融合反応の研 究である。すなわら、この研究では高密度のプラズマを非常に高い温度に加熱いかつ閉じ込み

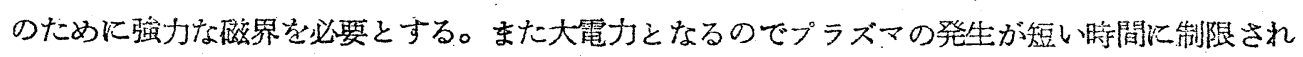
ている。このようなブラズマに於いては従来の測定法が適用できなくなるので新しい方法が必要

* K. Takama, S. Ohara, H. Ikegami. (The Electrical Communication Lab..Nihon Telegram and Telephone public Corporation, Tokyo) 
高山・大原・池上

となつた。この要求に答え得る有力な一つの方法として注目されたものが“マイクロ波猃断法” と呼ばれるマイクロ波によるブラズマの測定法である。

診断法の理論的研究の中で均一なプラズムに関するものは一応完成している。しかし実験 室で 必然的に附随する非均一なブラズマの理論的研究は今後に残されている。(

今日実験公で広く用いられているマイクロ波の測定には空胴法と干渉法がある。前者は共振器 中に適当な形のプラズマを入れて共振周波数のずれから電子密度を、また半值巾から衝突周波数 を求めるものである。後者はプラズマ中での $\mu$ 波の位相の変化と減亭係数から密度と衝突周波数 を求める方法である。いつれの場合にも磁界のあるときの湘定は簢単な特殊な状態に制限される(4) 干啮法では電波がブラズマを通過する必要があるので電子のプラズマ振動数より高い振動数の m波を必要とする。空胴法では $10^{9} / \mathrm{cm}^{3}$ 程度の密度が容易に測定されるが、近年 Persson (5) 及びBuchsbaum とBrownのによつて $10^{12} / \mathrm{cm}^{3}$ までの密度が湘定できることが示された。

これらの外に電磁波のプラズマからの反射の状態を湘定して密度を求める反射法がある。

反射法は実験公のプラズマ密度測定にはほとんど利用されていないが 波長がプラズマの半径 より大きい場合には高い密度まで測定される特色がある。Lovel1とClog g(7) は流星の跡 のブラズマに 8.3,6,5,42,及び $1.4 \mathrm{~m}$ の波長を用いて $10^{12} \mathrm{~cm}^{-3}$ の密度を測定している。実験窒で はPartrige とHarri ( $^{(8)}$ は小弾丸の通過後にできるプラズマに $10 \mathrm{~cm}$ のイクロ波を あてたときの反射係数と同じ半径の銅の棒から反射したものを比較することによつて $10^{14} \mathrm{~cm}^{-3}$ 以上の密度を测定している。

われわれの研究は反射法に属するが 上述のものと異つて陽光柱を導波管に聥入してある。長 、波長で高い密度のブラズマの測定を目標にし、陽光柱の密度分布を考慮した正確な理論から反 射係数を遵きこれによつて求めた密度と Langmuir 探針から求めたるのを比較することに よつて測定法を吟味したものである。導波管に㨂入した誘電体の反射係数の理論と実験(9)はすで になされているが、陽光柱の如く密度分布が一㥞でない場合の反射係数の計算はない。しかしマ イクロ波による密度測定値と探針による測定值を比較したものK Schulz と Brownl9の 研究がある。これは共振器内にマイクロ波によつてつくつたプラズマの電子密度を空胴法によつ て測定しこれをLangmu i r 探針のイオン捕集領域から求めたイオン密度と比較している。 かれらの結果は 0.1 man $\mathrm{Hg}$. 以下の任力に於いては電子密度とイオン密度はよく一致することを示 したが、圧力が $1 \mathrm{~mm} \mathrm{Hg}$ ，以上ではイオン密度が䉓子密度よりる大きく測定されている。

われわれの場合には陽炕柱のプラズマは直流放電によつてつくられガスの圧力は 0.1 m以上で ある。このような陽光柱は陽極振動と移動縞があつて探針測定は誤差が生ずるので振動の微小な 
マイクロ波反射法によるプラズマの密度測定

放電管により探針の飽和電子電流から電子密度を求めたものである。

実 験

§1. マイクロ波測定装置

この実験に用いた装置は为 1 因の如き通常の $\mu$ 波回路である。

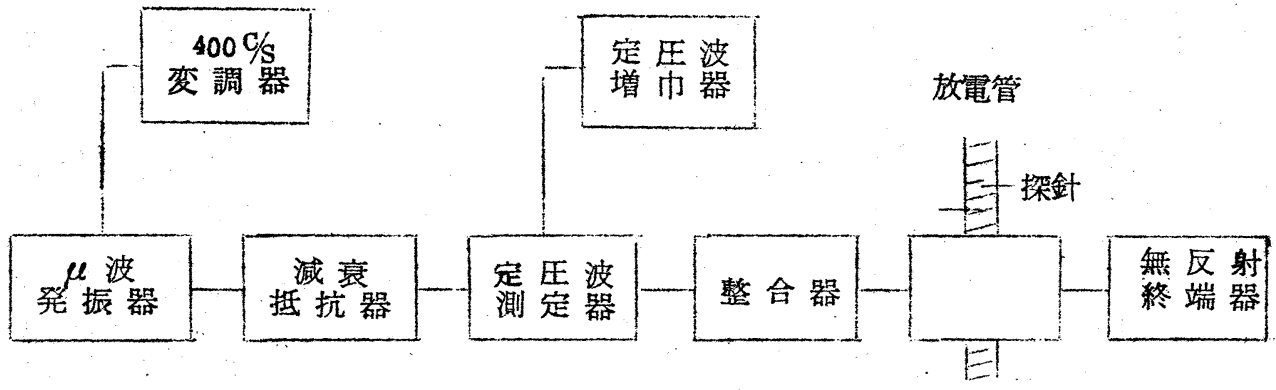

为1図実験，装 置

用いた $\mu$ 波の周波数は $4000 \mathrm{Mc} / \mathrm{s}$ 抢よび $1000 \mathrm{Mc} / \mathrm{s}$ の二種類である。区射係数の測定に は $\mu$ 波を $400 \%$ / 取ることが出来るようにしてある。

減哀器は $30 \mathrm{db}$ 以上の隇衰を入れて測定系と発振系との結合を防止してある。更に整合器は. 単一スタッブを用いて放電管ガラス壁からの反射を相殺する。導波管と放電管の結合は为 2 区に 示すような結合器を用いた。

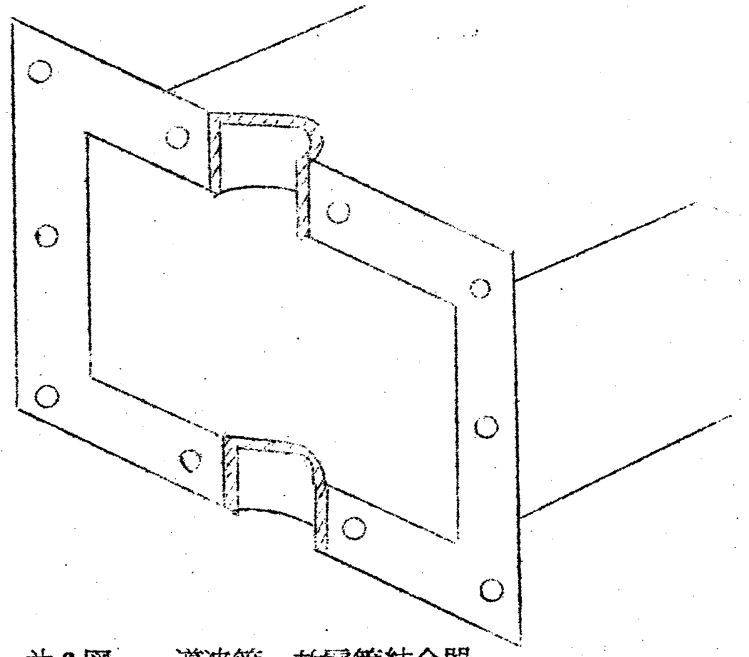

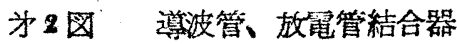


高山・大原・池上

この実験に用いた放電管はすべて熱陰極型で管内は大部分密度均一な陽光柱ブラズマである。 密度測定用として複探針が設けてあるがその露出部分は軸方向に向けて放電を乱さないようにし てある。複探針の一方は径方向に移動でき密度の径方向分布を測定する。

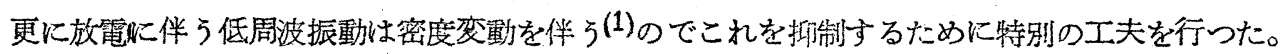
これは電極前面に゙網状グリッドを設けるものでこのようにした場合端子間振動電圧は $10 \mathrm{mV}$ 以下

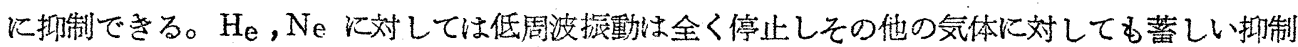
効果がある。特に陽極に原因のある振䱉に対してて完全に停止さすことができる。㓌極に原因の ある振動に詨しても効果が著しいがこのグリッドのみで振動の停止しない場会には除極近傍に磁 石をおいて之の位置を適当に調節すれば振動の止まることが多い。

このような方法で类験中は低周洨振動は全く除き雑音的な高周波振動も10 mV 以下におさえて 少く々も振動による密度変動はないようにした。为３図に放電管の構造を示す。
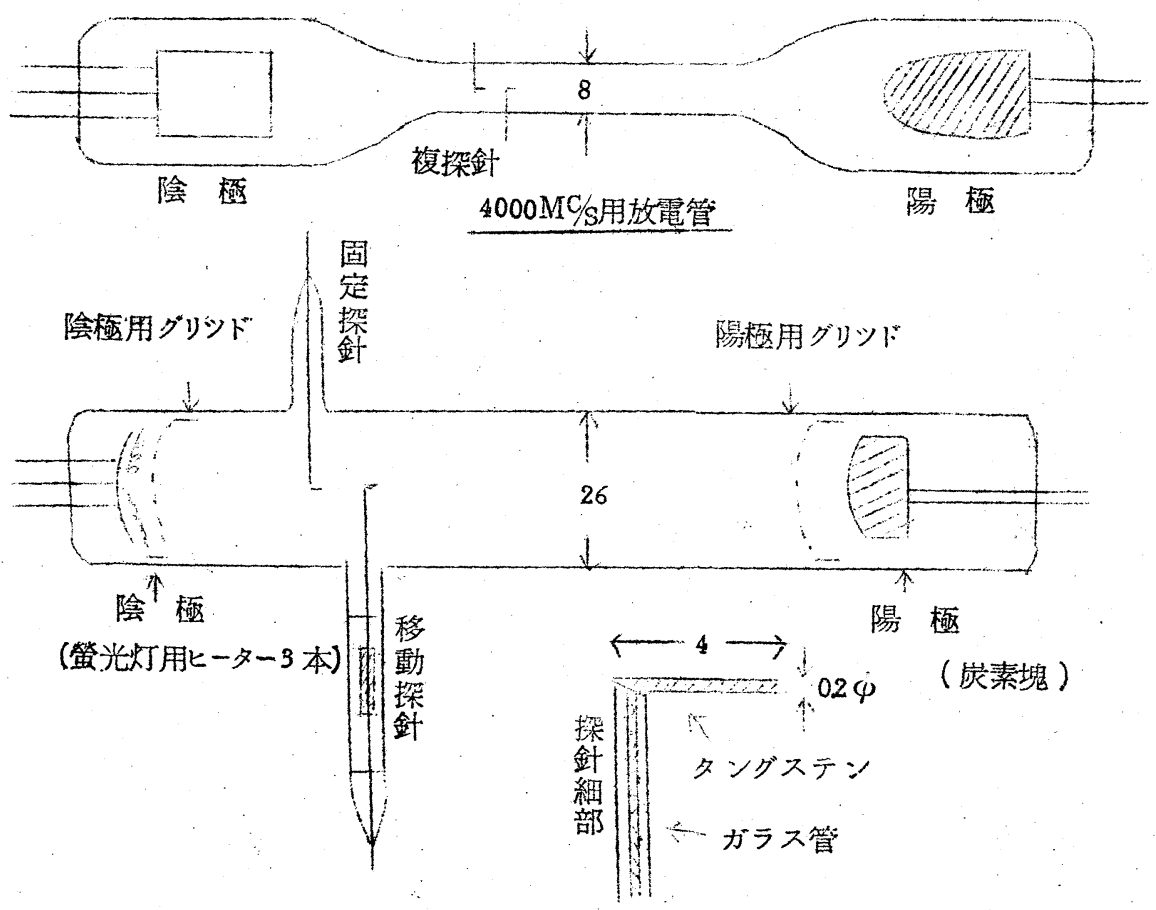

$1000 \mathrm{MC} / \mathrm{s}$ 用放電管

为3园放電管 
§2. マイクロ波測定結果

$1000 \mathrm{MC} / \mathrm{s}$ の波を用いてHeを $0.5 \mathrm{~mm} \mathrm{H}$ g入れた放電管の陽光柱プラズマの反射係数測定の結

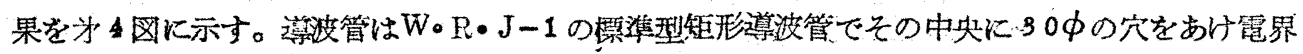
ベクトル汇平行に放電管を搜入した。尚使用モードは TE 10 である。

放霨管容器のガラスからの反射係数は 2 \%である。これは単一スタップで整合を取つてあるた ぬ相殺されて测定結果には影響はない。

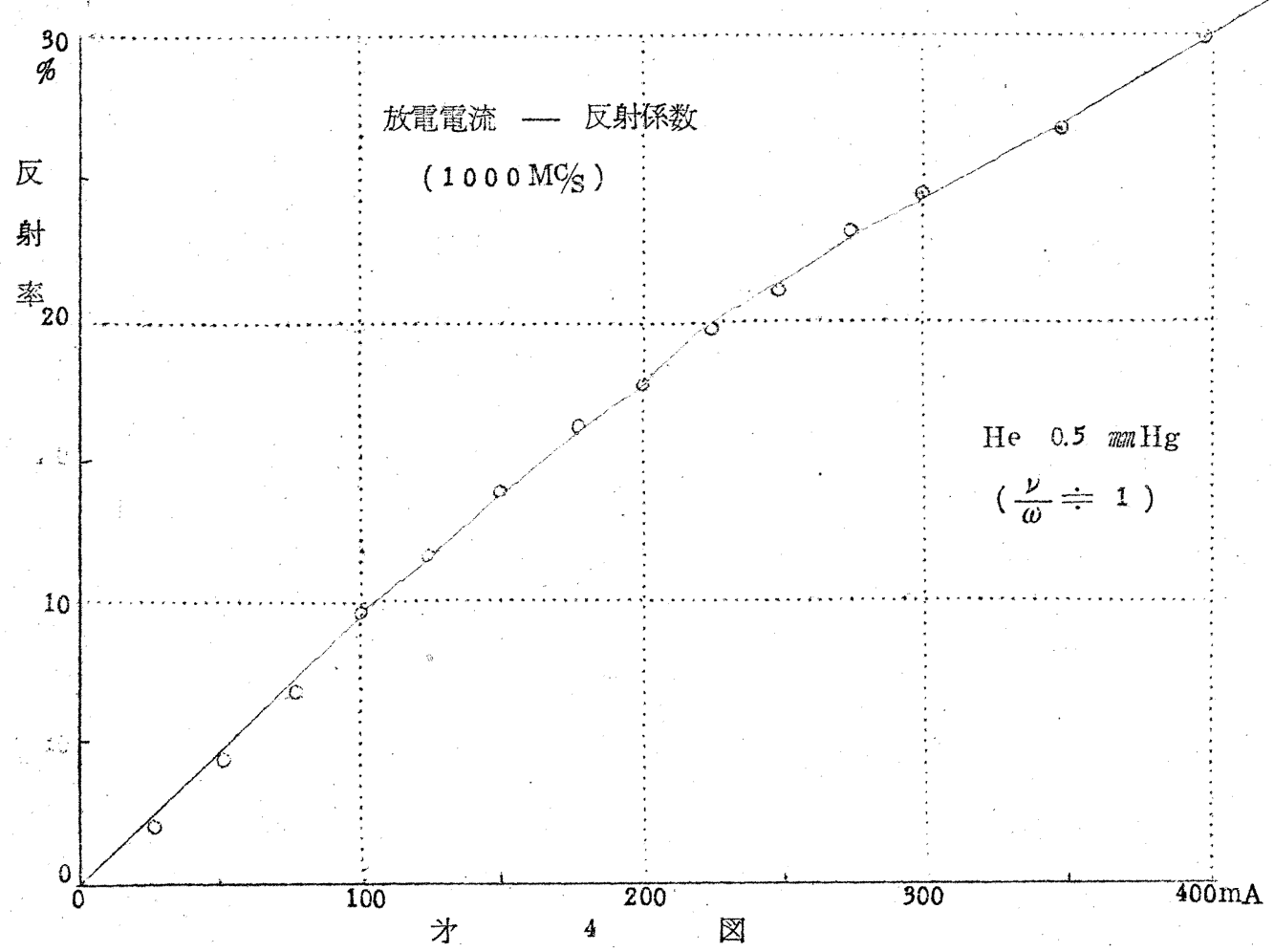

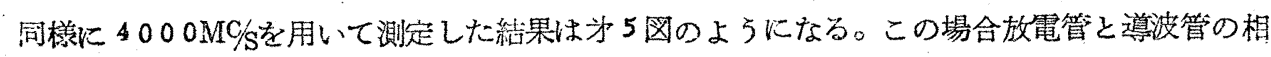
対的な関係は $1000 \mathrm{MC} / \mathrm{s}$ 場合と同じであるが管の大きさは8mめとなつている。

$4000 \mathrm{MC} / \mathrm{S}$ 使用した場合は $1000 \mathrm{MC} / \mathrm{S}$ に比して残留反射が大きく放電容器のガラスからの反 射子 $7 \%$ 以死る。 
高山・大原・池上

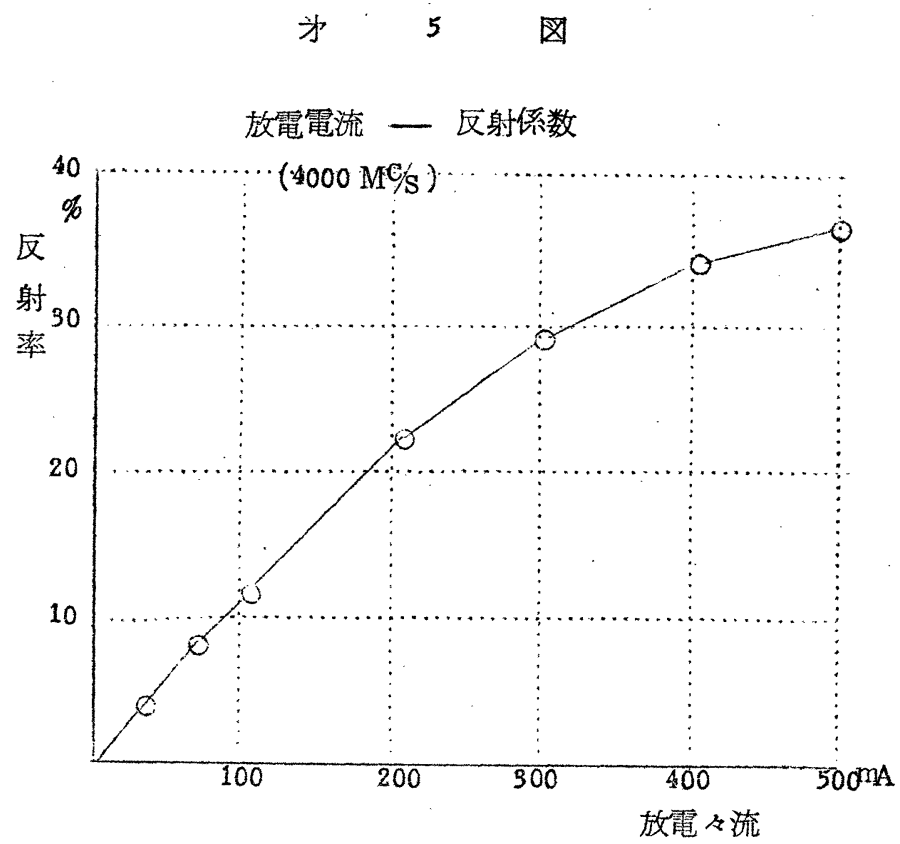

\section{3. 挆針による測定}

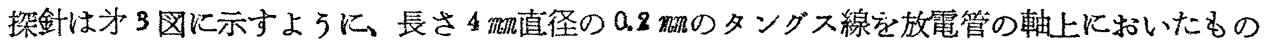
で、 $1000 \mathrm{MC} / \mathrm{s}$ 用放電管は径方向に平行移動が可能である。電流電王特性は時間的な諸量の変動 をできるだけとり入れないために、X一Y記録装置を用い、イオン電流飽和領域から電子電流飽 和領域までの $\mathrm{S}$ 型曲線を 10 秒以内で記録した。 $4000 \mathrm{MC} / \mathrm{S}$ 用放電管の探針測定は管径が細いた め探針による放電の乱れが大きく信頼出来る上うな密侵測定はできなかつた。以下述べることは $1000 \mathrm{MC} / \mathrm{s}$ 用の大きな放電管についての測定である。

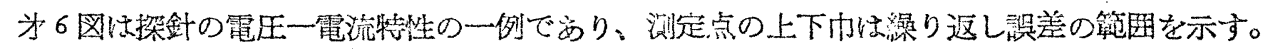
飽和点近くで直線性があり、電子電流の小さいところで下曲りの曲線婂なすのは、イオン篦流

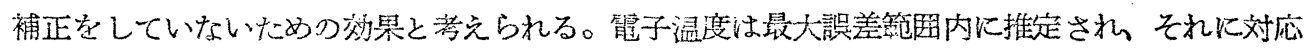
する密度範图が沃定された。 
マイクロ波反射法によるプラズマの密度測定

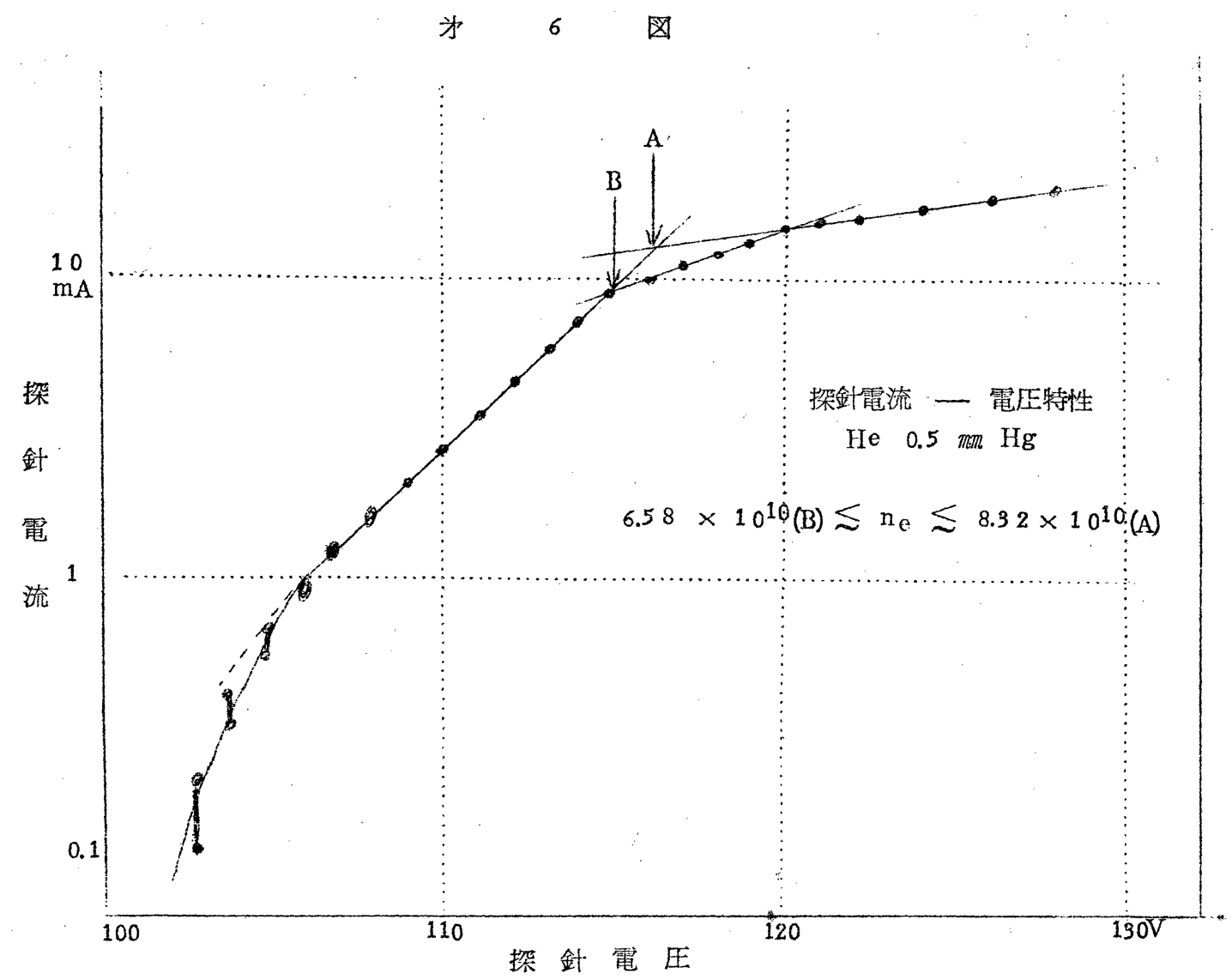

§4. 電 子 密 度

为て図には、放電々流を20 mAから500 mA まで変化させたときの、放電管中央での密度測定 の結果が示されている。

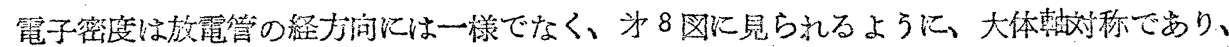

$$
N=N_{0}\left(1-\frac{r^{2}}{\rho 2}\right)
$$

の形の分布であると涔えてよさそうである。

これに基いて、マイクロ波反射倸数の計算では、密菨分布を放物線的で岁ると仅定した。

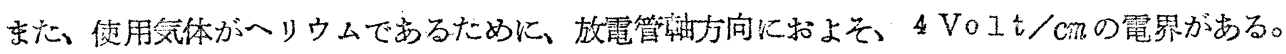

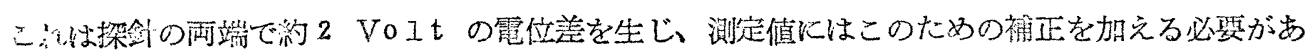




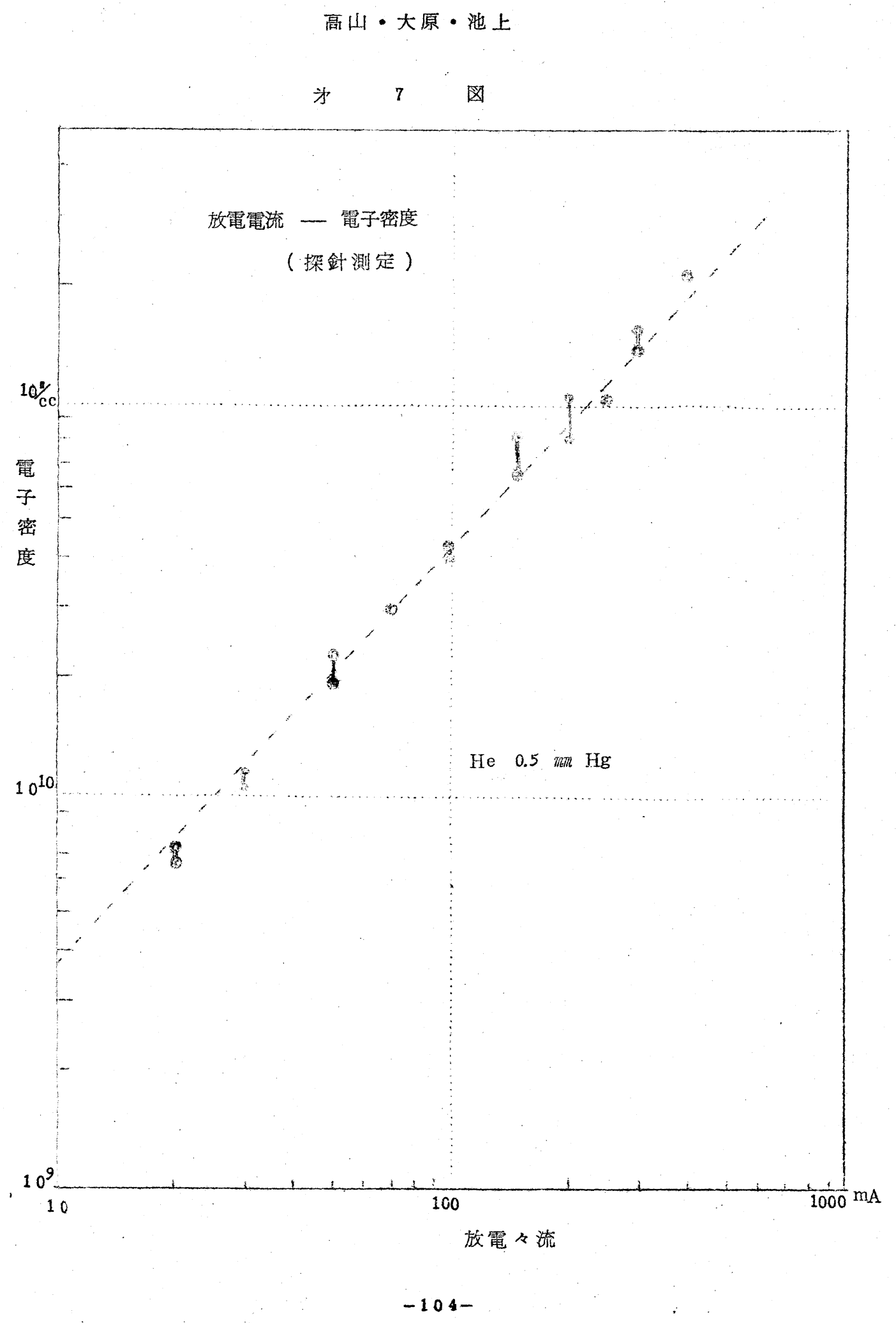


マイクロ波反射法によるブラズマの密度測定

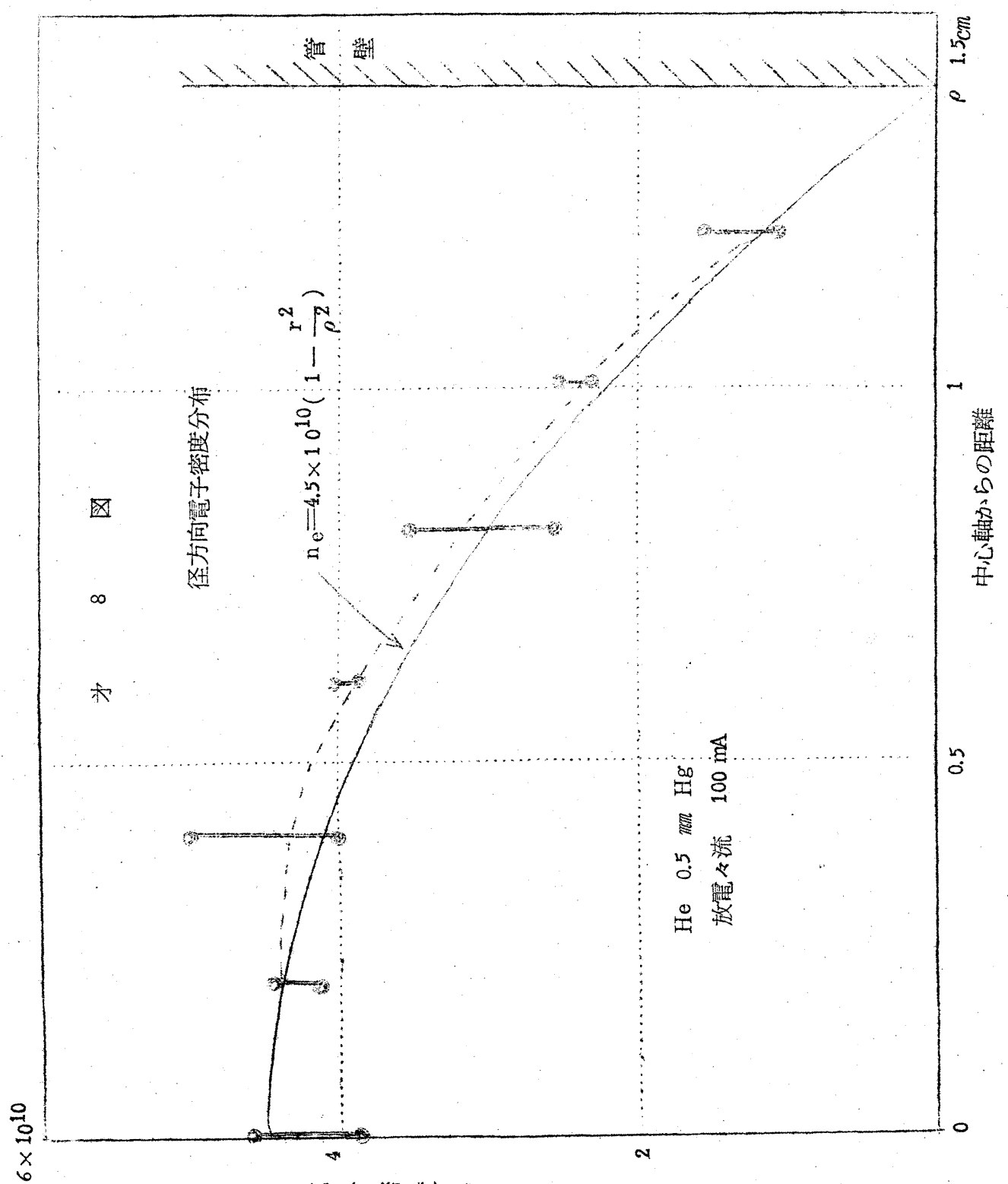

踝小然些。 
るかも知れないが、为 7 図ではなされていない。

管径方向の電界については、管壁から 1 mのところまでの、電位降下が 5 \%程度にすぎず、 殆ど考慮する必要はない。

電子温度は、放電々流 $20 \mathrm{~mA} 550000^{\circ} \mathrm{K} 、 400 \mathrm{~mA}$ ない

以上の密度測定值の信頼できる䉇囲は 2 析までで、3杵までの有効数字を期待できない。

一般に探針測定法に和いては、電子温度は比較的容易に、正確に求まるが 屓特性に拁ける

「肩の点」の決定にあいまいさがあり、密度の測定值の誤差の主な原因となつている。

注) 1) Langmuir - Mot t-Smith の探針法 ${ }^{(13)}$

電子電流飽和值を用いて電子密度を求め、電子電流と探針ブラズマ間電位差特性から電 子温度を求める。この方法の久点は、i) 電子電流飽和点 (ki nk) の決定に誤差が多い こと。ii）正イオン電流の電子電流に対する補正が困難なこと、従つて電子温度の決定 に誤差を生ずる。iii 飽和点附近では大きな電子電流をとるため プラズマへの㩭乱が大 きく、をた探針自体も加熱されて仕事函数が变化し熱電子放射など行い、時には探針自体 の熔触により測定が不可能になる。

2) Johnson-Molter の複探針法 (1)

プラズマから吸収する電流が正イオン飽和電流值により制限されるため、(1)に比し筧乱 が少いという利点と、空間電位の変化にあまり影響されないという利点をるち過渡ブラズ マの測定などに多く利用される。欠点は门電子密度が求められないこと、特に電子温度が 高い場合に問題がある。iD 空間電位の決定が本質的に不可能なことである。

3) Schultz-Brown の探針法 (10)

正イオン電流飽和領域からイオン密度を求める。従つて沢山の電流をブラズマから吸い とることによつて大きな攬乱を生ずるといつた心配はない。然しこの方法の久点は、门) 空間電位の決定が困難な場合は正確に密度が求まらない。ii) 測定值の取り扱いが複雑で あること。iid 理論的に、 T+を用いずTーを用いる criterion が明確でないこと。

以上は主として、夫々の方法に対する長所、短所であるが、探針測定に抬いては、探針 の捙入という事柄自体が攪乱をおこすことは不可避である。

また磁場がある場合とか負イオンが混在する場合の探針測定法はまた確立されていない。 測定結果の比較

マイクロ波による測定值为4四は放電々流とそれに対応する反射係数との関係を示しているが 
マイクロ波反射法によるブラズマの密度測定

直接には密度をあたえていない。後に示すように理論によれば反射係数と密度の関係を求めるこ とができる。

反射係数 Rは (47) 式Kより、

$$
\begin{aligned}
\mathrm{R} & =-\frac{4}{a \sqrt{\mathrm{k}^{2}-\left(\frac{\pi}{\mathrm{a}}\right)^{2}}}\left[2 \mathrm{H}_{0}^{(2)}(\mathrm{ka})+f_{0}(\mathrm{k} \rho)^{-1}-1\right. \\
& -\mathrm{j} \frac{8 \sqrt{\mathrm{k}^{2}-\left(\frac{\pi}{2}\right)}}{8}\left[2 \widetilde{H}_{0}^{(2)}(\mathrm{ka})+\mathrm{H}_{2}^{(2)}(\mathrm{ka})+f_{1}\left(\mathrm{k} \rho ; \mathrm{n}^{2}\right)^{-1}\right]^{-1}
\end{aligned}
$$

函数 $f_{\mathrm{n}}(\mathrm{k} \rho)$ は $(29)$ 式により

$$
f_{\mathrm{n}}(\mathrm{k} \rho)=\frac{\left(\mathrm{T}_{\mathrm{m}}\left(\mathrm{k} \rho ; \mathrm{n}^{2}\right) \mathrm{Tn}(\mathrm{k} \rho)-\left(\mathrm{T}_{\mathrm{m}}^{\prime}\left(\mathrm{k} \rho ; \mathrm{n}^{2}\right) \mathrm{T}_{\mathrm{m}}(\mathrm{k} \rho)\right.\right.}{\left.\mathrm{G}_{\mathrm{m}}\left(\mathrm{k} \rho ; \mathrm{n}^{2}\right) \mathrm{H}_{\mathrm{n}}{ }^{(2)}\right)(\mathrm{k} \rho)-\mathrm{G}_{\mathrm{m}}^{\prime}\left(\mathrm{k} \rho ; \mathrm{n}^{2}\right) \mathrm{H}_{\mathrm{m}}{ }^{2}(\mathrm{k} \rho)}
$$

である。Rに対して上の近似式を用いるための条件は

$$
\operatorname{Re}\left|(\mathrm{nk} \rho)^{2}\right| \ll 10
$$

である。尚 $1000 \mathrm{MC} / \mathrm{s}$ てイクロ波に対する諸数值は脚註に示した。

本実験 $\left(\mathrm{H}_{\mathrm{e}} \quad 0.5 \mathrm{~mm} \mathrm{Hg}\right)$ では、 $\frac{\nu}{\omega} \doteqdot 1$ である。 $\frac{\omega 0}{\omega}$ をあたえるとnが決まり反射係数 $|\mathrm{R}|$ が計算される。こつに合は後に示されるように、プラズマ円柱中心部の最高密度に対する電子 プラズマ角振動数である。

函数 $\mathrm{Gn}(\mathrm{k} \rho)$ の計算は $(48)$ 式以下に見られる級数展開により行われ、

$$
\operatorname{Re}\left|(n k \rho)^{2}\right| \ll 10
$$

(脚註）：

$$
\begin{gathered}
\frac{4}{\mathrm{a} \sqrt{\mathrm{k}^{2}-\left(\frac{\pi}{\mathrm{a}}\right)^{2}}}=0.9718 \\
\frac{8 \sqrt{\mathrm{k}^{2}-\left(\frac{\pi}{\mathrm{a}}\right)^{2}}}{\mathrm{ak} \mathrm{k}^{2}}=0.1879 \\
\mathrm{k} \rho=0.3 \\
\mathrm{ka}=5,180 \quad \mathrm{ka}=\mathrm{q} \pi \quad \mathrm{q}=1.65 \\
\widetilde{\mathrm{H}}_{0}^{(2)}(\mathrm{ka})=-0.0146-\mathrm{j} 0.2372 \\
\widetilde{\mathrm{H}}_{2}(2)(\mathrm{ka})=0.1288+\mathrm{j} 0.2363 \\
-107-
\end{gathered}
$$


高山・大原・池上

の条件下では $\mathrm{G}_{\mathrm{n}}(\mathrm{k} \rho)$ )代りに (49) 式の $\overline{\mathrm{Gn}}(\mathrm{k} \rho)$ を用いてよいことがわかる。 $\overline{\mathrm{Gn}}(\mathrm{k} \rho)$ の近似式を用いた場合の計算值を表 1 及び矛 9 図に示す。

表 1

\begin{tabular}{|c|c|c|c|c|c|c|c|c|c|c|}
\hline$\left(\frac{\omega_{0}{ }^{2}}{\omega}\right)^{2}$ & 0 & 0.1 & 0.2 & 0.3 & 0.4 & 0.5 & 0.6 & 0.7 & 0.8 & 0.9 \\
$\mathrm{R}$ & 0 & 0 & 0.426 & 0.886 & 1.13 & 1.46 & 1.70 & 1.99 & 2.22 & 2.49 \\
\hline$\left(\frac{\omega_{0}}{\omega}\right)^{2}$ & & 1 & 2 & 3 & 4 & 5 & 6 & 7 & 8 & 9 \\
$\mathrm{R}$ & & 2.73 & 5.55 & 8.36 & 11.2 & 14.4 & 17.2 & 20.1 & 23.1 & 26.2 \\
\hline$\left(\frac{\omega_{0}}{\omega}\right)^{2}$ & & 10 & 20 & 30 & 40 & & & & & \\
$\mathrm{R}$ & & 29.3 & 58.8 & 81.9 & 96.2 & & & & & \\
\hline
\end{tabular}

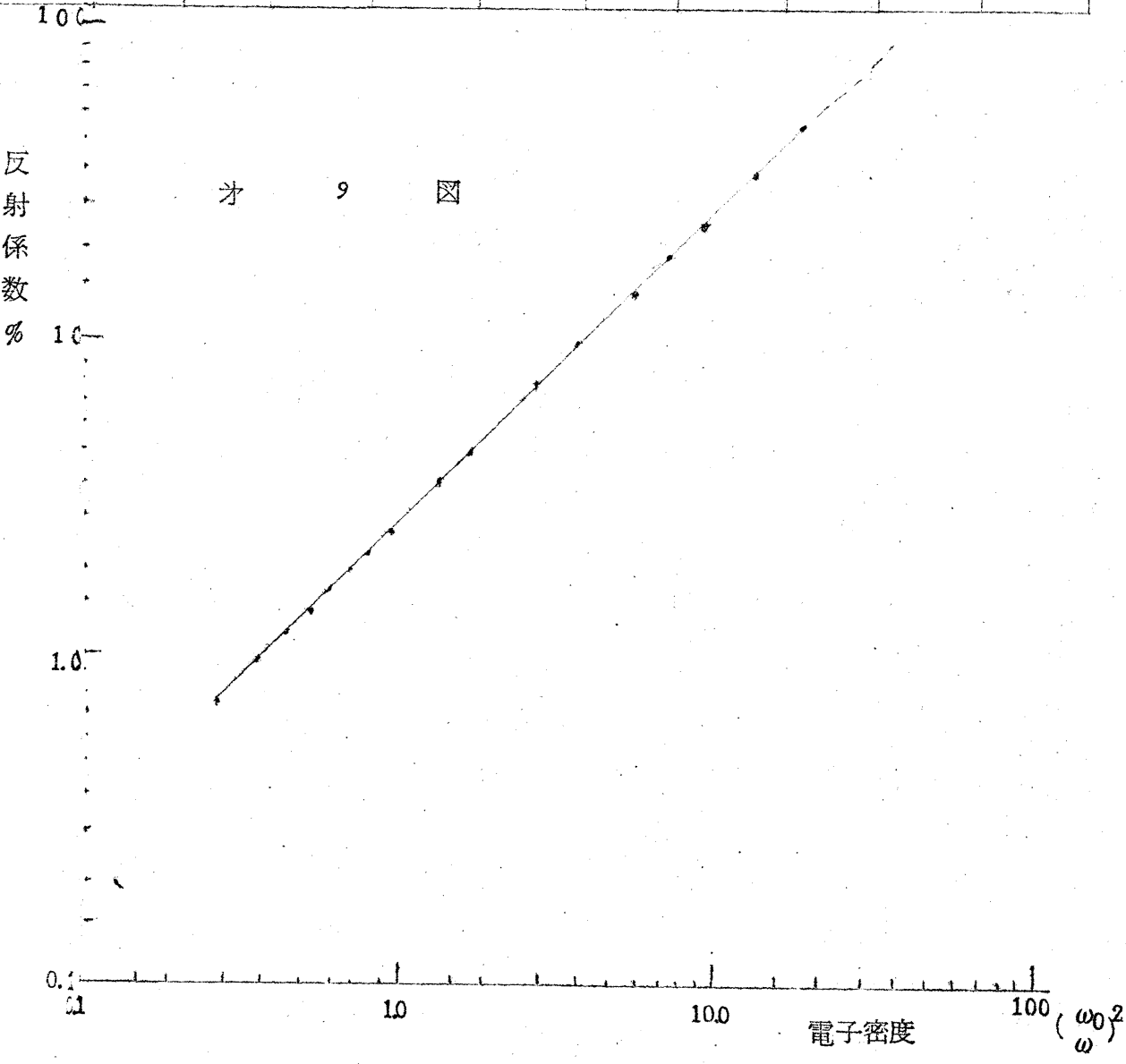


マイクロ波反射法によるプラズマの密度測定

为9図及び为4 図を用いるとマイクロ波測定による反射係数からプラズマ密度と放電電流との 関係を求めることができる。これを探針法による測定值と比敷したものが为 10 図である。

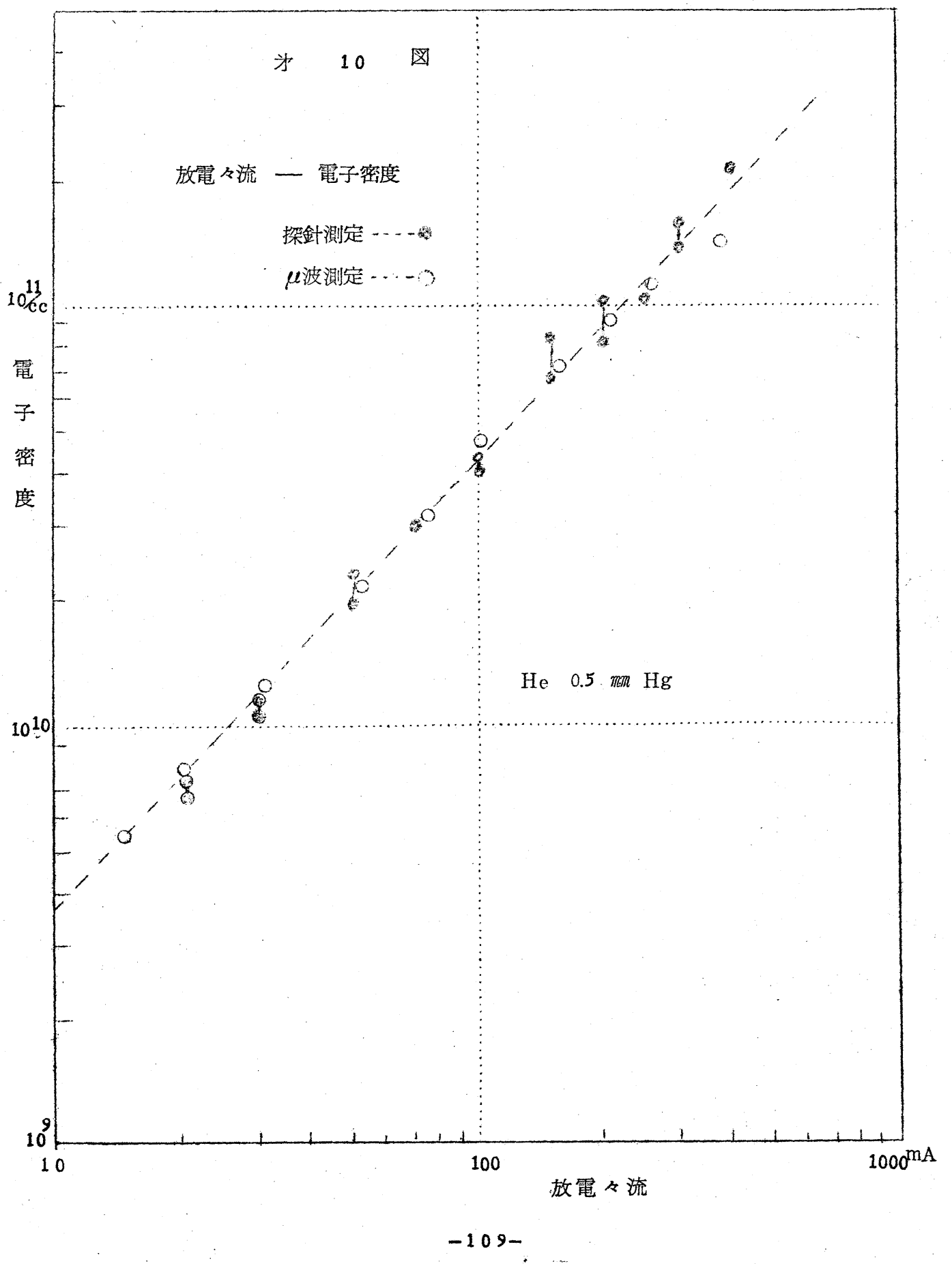


高山・大原・池上

$1000 \mathrm{MC} / \mathrm{S}$ に対応する電子プラズマ振動数をあたえる電子密度は $1010 / \mathrm{c}$ cであるが

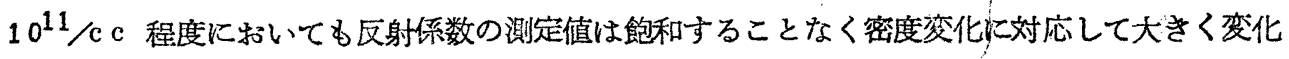
することは注目に值する。

为 10 図では電子密度が $1011 / \mathrm{c} c$ 以上になると両測定值が一致しなくなる。その原因を考察 してみよう。

マイクロ波湘定法に関しては $\mathrm{G}_{\mathrm{m}}\left(\mathrm{k} \rho ; \mathrm{n}^{2}\right) \simeq \overline{\mathrm{G}_{\mathrm{m}}}\left(\mathrm{k} \rho ; \mathrm{n}^{2}\right)$ の近似が正しくなくなること が最大の原因と洘えられる。 $\mathrm{Gm}\left(\mathrm{k} \rho ; \mathrm{n}^{2}\right)$ の高次項までとつて計算を行党ば、よりよい一致が 見られる筈である。

放電電流が小さい場合にはプラズマよりもガラス容器壁による反射の方が大きくなり整合をと つたとしてす影響が残ることが予想されるが为 10 図にはとの結果は表われていない。

放電々流を变化させたとき、プラズマ円柱の半径が変化し、また密度の分布が異つてくること る当然考えられるがこつではそのための考虑はされていない。

更にプラズマ円柱を舫入したための導波管壁の"空“による損失る $\mathrm{k} \rho=0.3$ では無視できる と考えた。しかしアンテナ効棵があるものとすれば簢単には済まされないがこの点についても無 視した。

探針測定に関しては、测定健に誤差を生じさせる原因が多く探針法の理論そのるのにも不完全 な面が多い。

a) 電子電流飽和点 (肩特性) の決定が因蜼。

この様子は为 6 図に見られる通りであるか原因としては

1) 陽光柱の振動 (空間電位、密度の变動)

ii）探針表面の仕事函数が電子電流增加に伴つて変化する。

iii) 電子の速度分布が MaxweI工 分布からずれる。

iv）探針が空間電位に近ずき篦子電流が壇すための放電の擾乱。

V）探針表面での電子の反射

等古洘えられる。このらち门は振動を抑制する特殊な放電管を用いることにより，门は $\mathrm{X}-\mathrm{Y}$ 記録装置を朋いて短時間の間に特泾をとることにより防がれている。iiD iり り 影響は小さいるのと期待される。

b) 電子温度の決定が困無

特にHe ガスを用いた場合イオン電流が多いため正確に電子電流成分を求めることが困 難になつて電子温度の決定に誤差を生ずる。 
マイクロ波反射法によるブラズマの密度測定

重いガスの場合には、イオン電流は小さく電子温度は比較的容易に求められる。

尚 a) の各条件はすべて電子温度の決定をる不正確にする。

更に探針を搟入した場合、陽光柱内でその部分の温度が低く極端な場合には陽光柱が探針を避 けて迁䞽するのが見られる。

すでに探針测定の章で述へられたよ5に $4000 \mathrm{MC} / \mathrm{s}$ 道波管のための細い導波管では、この迁 廻の様子がはつきり見えるため探針測定は正確にできなかつた。

また円柱探針では「端の効果」を一般に無視できない。特に低密度になる程との効果が大きく なるがっこれは電子密度測定に 10\% 以上の誤差をもたらさないものと概算された。

放電々流を增していくと空間電位勾配は幾分減少する傾向をみせるが大体 2 VoIt/cn６電界 が保たれる。これが探針の各部分に異つた電位を与えることになるがこの影響す誤差範囲内であ ろうと考えられる。

このように検討を進めてくると探針による密度測定法にも種々のあいまいさがあり十分な精度 は望をれないことが知れる。

従つて为 10 圀の一致は十分に满足すべきものであると言わざるをない。

マイクロ波とよる一様でないプラズマの電子密度浿のための計算

§1.プラズマ円柱内のマイクロ波電界

覚波管内に設置された誘電物体によるマイクロ波の反射吸収については、すでに詳細な計算が なされている。(15)(16)(17) しかしながら、これらは一様な媒質としての誘電体を考えた場合の取 扱いであつて、不均一媒質に対しては二、三の数値計算による結果 ${ }^{(18)}$ を除いては、基本的な計 算例は見当らない。

ここでは媒質の不均一性を考虑しながら、Maxwe 11 の基礎方程式から基本的な計算を行う。 導波管内の笔磁波については、管に沿ってx軸をとれば、壁面で電界が满足すべき条件は、電 界の $\mathrm{x}$ 成分と断面の周辺に沿つた接線成分とが共に零になることである。

T E 型電磁波を考兄よう。これは進行方向に電界成分をるたない。最も簡単な T E 10 型は、 導波管断面の短い方の辺に沿つて $\mathrm{z}$ 軸をとると、電界強度ベクトルとしては $\mathrm{z}$ 成分しかむたない。 


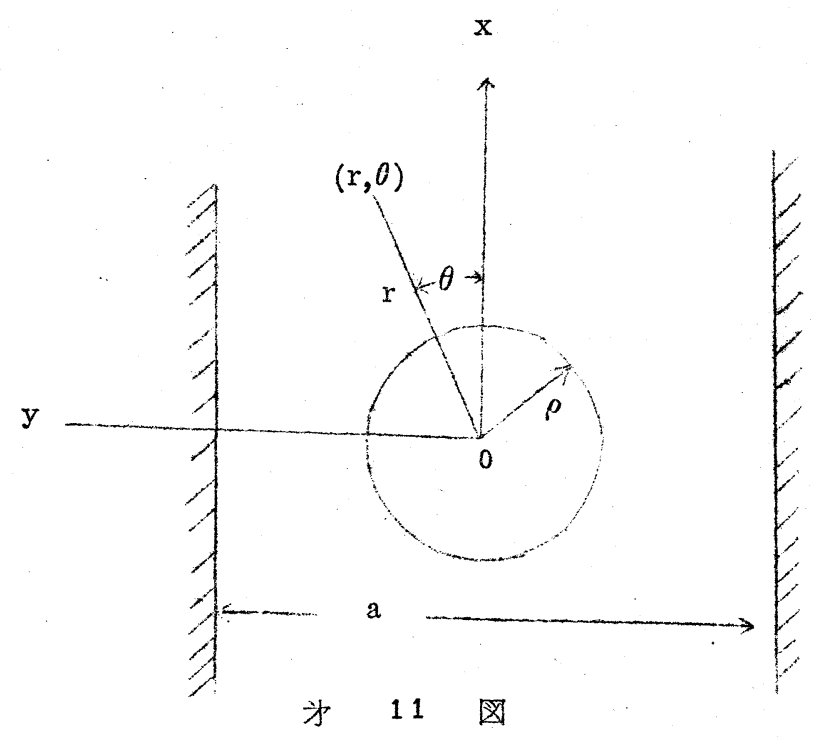

図 11 の如く導波管の中央を貫いて、 $\mathrm{E}_{\mathrm{z}}$ に平行に設置されたプラズマの円柱を想定しよう。 プラズマが放電管中の陽光柱である場合、電子密庭は軸坟称で、径方向には０次为一種 Bes s e I 函数の分布をすることが知られている。

プラズマを半径 $\rho$ の円柱としたとき、プラズマ内での電子密度分布を、軸に沿つて一稼 径方 向には軸対称で次の上うに表方されると仮定しょう（註参照）

$$
N(r)=N_{0}\left(1-r^{2} / \rho^{2}\right)
$$

钭 $\mathrm{N}(\mathrm{r})$ が为一種 0 次 Besse工 函数の場合には

$$
\begin{aligned}
N(r) & =N_{0} J_{0}(2.405 \mathrm{r} / \rho) \\
& \simeq N_{0}\left(1-1.446 \mathrm{r}^{2} / \rho^{2}+0.5227 \mathrm{r}^{4} / \rho^{2}+\cdots \cdots\right) \\
\text { 従つr } \mathrm{r} / \rho & \ll 1 \quad \mathrm{~N}(\mathrm{r}) \simeq \mathrm{N}_{0}\left(1-1.446 \mathrm{r}^{2} / \rho^{2}\right) \\
\mathrm{r} / \rho & \simeq 1 \quad \mathrm{~N}(\mathrm{r}) \simeq \mathrm{N}_{0} 1.248 \mathrm{r} / \rho
\end{aligned}
$$

にあわせるようにするのが最も望ましい。

プラズマ円柱内に括いて TE10型マイクロ波の電界、

$$
E_{z}=\varphi(x, y) \quad \exp (+j \omega t)
$$

が满足すべき方程式を求めよう。

MaxweII方程式より容易に次の波動方程式が尊かれる。 


$$
\nabla^{2} \mathbf{E}-\frac{\varepsilon}{c^{2}} \frac{\partial^{2}}{\partial t^{2}} \mathbf{E}-\frac{4 \pi \sigma}{c^{2}} \cdot \frac{\partial \mathbf{E}}{\partial t}=\operatorname{grad} \text { div } \mathbf{E}
$$

媒質は $z$ 軸方向に一様であり、従つて譛電率 $\varepsilon$ も $z$ 軸方向に一様であるから $D=\varepsilon \mathbb{E}$ とおくこ とができる。(3)式の左辺で矛三項は電気伝遵率のを用いて 霓流 JとEとの間に J J Ohm の法則を適用しEをJで打きかえた。

以後特に必亚でない限り(2)式の時間因子を除いて考える。(3)式冲次の上うに畫き改められる。

$$
\frac{\partial^{2} \varphi}{\partial x^{2}}+\frac{\partial^{2} \varphi}{\partial y^{2}}+\left(\varepsilon \frac{\omega^{2}}{c^{2}}-i \frac{4 \pi \sigma}{c^{2}} \omega\right) \varphi=0
$$

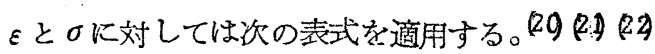

$$
\begin{aligned}
& \varepsilon=1-\frac{\omega_{\mathrm{p}}{ }^{2}}{\omega^{2}+\nu^{2}} \\
& \sigma=\frac{\nu}{4 \pi} \frac{\omega_{\mathrm{p}}{ }^{2}}{\omega^{2}+\nu^{2}}
\end{aligned}
$$

עは衝咨角掁動数、 $\omega_{\mathrm{p}}$ はプラズマ角振動数である。

$$
{ }^{\omega} \mathrm{p}^{2}=\frac{4 \pi \mathrm{Ne}^{2}}{\mathrm{~m}}
$$

NK対しては、(1)式の表式が適用されるからととのはrの函数である。

(5)(6)式を導く際には次の様な仮定がなされていることに注意しなければならない。(20)

i） レがエネルギーによらず一定

ii) マイクロ波のエネルギーは十分小さい。すなおち摂動程度。

(4)式を为 11 図に従つて円柱座標系で表示すると、

$$
\frac{1}{\mathrm{r}} \frac{\partial}{\partial \mathrm{r}}\left(\mathrm{r} \frac{\partial}{\partial \mathrm{r}}\right) \varphi+\frac{1}{\mathrm{r}^{2}} \frac{\partial^{2} \varphi}{\partial \theta^{2}}+\mathfrak{x}^{2} \varphi=0
$$

æは自由空間での波数 $\mathrm{k}$ 及び(5)(6)式の表示を用いて次のように定義する。

$$
æ^{2} \equiv \mathrm{k}^{2}\left(1-\frac{\omega \mathrm{p}^{2}}{\omega^{2}+\nu^{2}}-\mathrm{j} \frac{\omega \mathrm{p}^{2}}{\omega^{2}+\nu^{2}} \frac{\nu}{\omega}\right)
$$

$\varphi$ は変数分離により

$$
\varphi(r, \theta)=\sum_{n=0}^{\infty} C_{m} G_{m}(r) \cos m \theta
$$

と表わされる。G(r)は合流型超幾何函数である。即ち(8)式を变数分離したとき $\mathrm{r}$ 部分は分離定数 
mを用いて

$$
\frac{1}{\mathrm{r}} \frac{\mathrm{d}}{\mathrm{dr}}\left(\mathrm{r} \frac{\mathrm{dG}}{\mathrm{dr}}\right)+\left[\mathrm{n}^{2} \mathrm{k}^{2}+\alpha^{2} \mathrm{k}^{2} \mathrm{r}^{2} / \mathrm{p}^{2} \mathrm{~m}^{2} / \mathrm{r}^{2}\right] \mathrm{Gm}=0
$$

こィ

$$
\left\{\begin{array}{l}
\mathrm{n}^{2}=1-\frac{\omega_{0}^{2}}{\omega^{2}+\nu^{2}}-\mathrm{j} \frac{\omega_{0}^{2}}{\omega^{2}+\nu^{2}} \\
\omega_{0}{ }^{2}=4 \pi \mathrm{N}_{0} \mathrm{e}^{2} / \mathrm{m} \\
\alpha^{2}=1-\mathrm{n}^{2}
\end{array}\right.
$$

Noは(1)式に見られるように密度の最大值である。更に次の变数変換を行い

$$
\begin{aligned}
r^{2} & =-j \frac{\rho}{k \alpha} \cdot t \\
G_{m} & =y m \sqrt{\frac{\rho}{i k \alpha} t}
\end{aligned}
$$

(11) 式を閽き直すと次の式がえられる。

$$
\frac{\mathrm{d}^{2} \mathrm{ym}_{\mathrm{m}}}{\mathrm{d} \mathrm{t}^{2}}+\left[-\frac{1}{4}-j \frac{\mathrm{n}^{2} \mathrm{k} \rho}{4 \alpha \mathrm{t}}+\frac{\mathrm{m}^{2}-1}{4 \mathrm{t}^{2}}\right] \mathrm{y}_{\mathrm{m}}=0
$$

これは Whittaker の微分方程式(23)に外ならない。

（12）式の解は

$$
\begin{aligned}
y_{m}= & C_{1} e^{-\frac{t}{2}} t^{\frac{1+m}{2}} F\left(\frac{1+m}{2}+j \frac{n^{2} k \rho}{4 \alpha} ; 1+m ; t\right) \\
& +C_{2} e^{-\frac{t}{2} t^{\frac{1}{2}} \frac{m}{2}} F\left(\frac{1-m}{2}+j \frac{n^{2} k \rho}{4 \alpha} ; 1-m ; t\right)
\end{aligned}
$$

こつでmは正擎数である。

$$
\mathrm{F}(\alpha ; \beta ; \mathrm{t})=1+\frac{\alpha}{1 ! \beta} \mathrm{t}+\frac{\alpha(\alpha+1)}{2 ! \beta(\beta+1)} \mathrm{t}^{2}+\cdots \cdots \cdots \cdots
$$

座標原点 $(r=0)$ Kおいて有限な值をるつ函数 $\mathrm{Gm}(\mathrm{r})$ は (13) 式右辺为一項により与えられ る。 


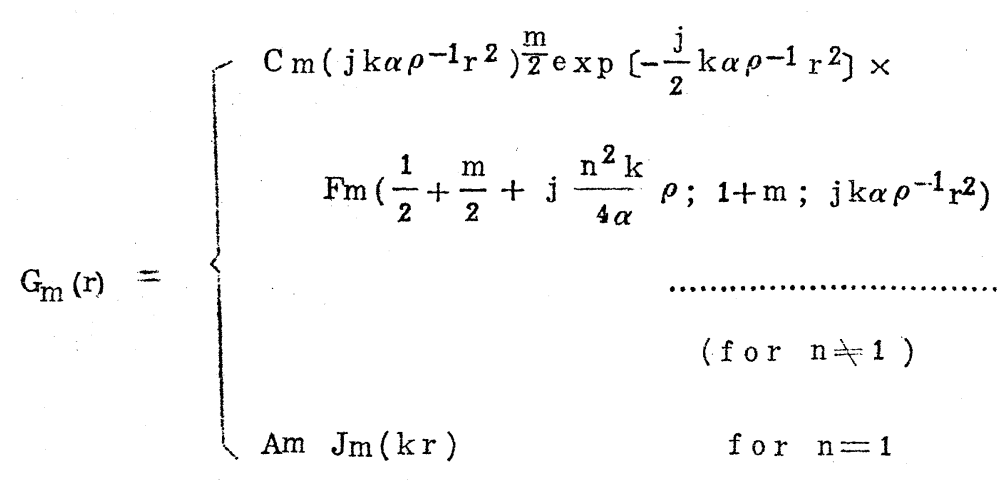

よつて求めるべきプラズマ円柱内の電界の形は（14）式を(10) 式に代入してえられる。

尚（15）式以真空中に批る電酳波の波動函数を円柱座標系に表示したものに過ぎない。 遵波管内で $\mathrm{TE}_{10}$ 型波

$$
E=\cos \frac{\pi}{\mathrm{a}} \mathrm{y} \mathrm{e}^{-\mathrm{jkx} \sin \phi}
$$

を円柱座標で表示すると、(15)式において

$$
\begin{aligned}
& A_{0}=1 \\
& A_{2 n}=2 \cos 2 n \phi \\
& A_{2 n+1}=-j 2 \sin (2 n+1) \phi
\end{aligned}
$$

としたものに相当する。こつに

$$
\mathrm{kg} / \mathrm{k}=\sin \phi
$$

であつて、kg は管内波数である。

$$
\mathrm{kg}=\sqrt{\mathrm{k}^{2}-(\pi / \mathrm{a})^{2}}
$$

自由空間においては、(16)式において $\phi=\frac{\pi}{2}$ としたときの $\mathrm{Am}$ の值を用いればよい。

\section{§ 2. 導波管内の散乱波電界}

波動方程式(8)式の解は、æが一定の場合一般に次の形で表わされる。 


$$
\sum_{\mathrm{n}} \mathrm{C}_{\mathrm{n}} Z_{\mathrm{n}}(æ r) \exp ( \pm \mathrm{jn} \theta)
$$

パラメーターnは解の一意性により整数值のみをとり、 $\mathrm{Zn}$ は一般の $\mathrm{n}$ 次円筒函数を表わす。 自由空閒に打いて (15) 式形の円柱に向了入射波を考光る(为 1 図参照)、その散乱波は次の 形に表わされる。

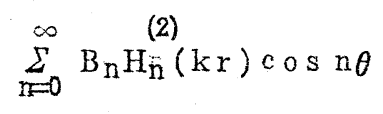

(17) 式は導波管の壁を考えない場合であるが、導体の壁がある場合、これらの散乱波は壁によ り完全反射されて杘つてくる。且つ一回の反射によつでの位相差を生ずる。

これら反射淡は鏡像法を用いると、y 軸上相互にaだけつつ雄れた無限個の点からの輻射の集 積として求められる。

原点○より $\mathrm{p}$ だけy韩上正又は負の方向に離れた点を $\mathrm{O}_{\mathrm{p}}{ }^{+}$及び $\mathrm{O}_{\mathrm{p}}$ 一表わすことにする。 $\mathrm{O}_{\mathrm{p}}$ からの輻射は管内でP回反射された波に相当する。为 12 図に従つて $r_{\mathrm{p}} \pm, \theta_{\mathrm{p}}$ 士を定義する と、区射波の集積は、

$$
\sum_{t,-} \sum_{\mathrm{p}=1}^{\infty} \sum_{\mathrm{n}=0}^{\infty}()^{\mathrm{p}} \mathrm{B}_{\mathrm{n}} \mathrm{H}_{\mathrm{n}}^{(2)}\left(\mathrm{kr}_{\mathrm{p}}^{ \pm}\right) \cos \mathrm{n} \theta_{\mathrm{p}} \pm
$$

で表わされる。

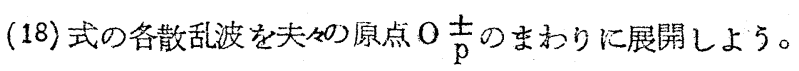

$$
r_{p} \pm=\left[r^{2}+(p a)^{2}-2 p a r \cos \left(\frac{\pi}{2} \mp \theta\right)\right]^{\frac{1}{2}}
$$

であるから、BesseI函数の公式 $(24)$ ょり

$$
\begin{aligned}
\mathrm{H}_{\mathrm{n}}{ }^{(2)}\left(\mathrm{kr}_{\mathrm{p}}^{ \pm}\right) \cos \mathrm{n} \theta \frac{\mathrm{p}}{\mathrm{p}}=\sum_{\mathrm{m}=-\infty}^{\infty} \mathrm{H}_{\mathrm{l}+\mathrm{m}}^{(2)}(\mathrm{pka}) \mathrm{J}_{\mathrm{m}}(\mathrm{kr}) \\
\times \cos \left\{\frac{\mathrm{n}}{2} \pi-\mathrm{m}\left(\frac{\pi}{2} \mp \theta\right)\right\} \quad \ldots \ldots . .
\end{aligned}
$$

これを(18)式に代入、（17）式をも含めると、導波管内での散乱波 $\mathrm{E}_{\mathrm{B}}$ がえられる。

$$
\begin{aligned}
\mathrm{E}_{\mathrm{B}}=\sum_{\mathrm{n}=0}^{\infty} \mathrm{B}_{\mathrm{n}} \mathrm{H}_{\mathrm{n}}^{(2)}(\mathrm{kr}) \cos \mathrm{n} \theta+\underset{\mathrm{n}=0}{2} \sum_{\mathrm{m}=\infty}^{\infty} \sum_{\mathrm{n}}^{\infty} \widetilde{\mathrm{H}}_{\mathrm{n}+\mathrm{m}}^{(2)}(\mathrm{ka}) \mathrm{Jm}(\mathrm{kr}) \times \\
\quad \times \cos \frac{\mathrm{n}-\mathrm{m}}{2} \pi \cdot \cos \mathrm{m} \theta \ldots \ldots \ldots \ldots \ldots \ldots \ldots \ldots \ldots \ldots \ldots \ldots \ldots \ldots \ldots \ldots \ldots \ldots \ldots \ldots \ldots \ldots \ldots \ldots \ldots
\end{aligned}
$$


栒

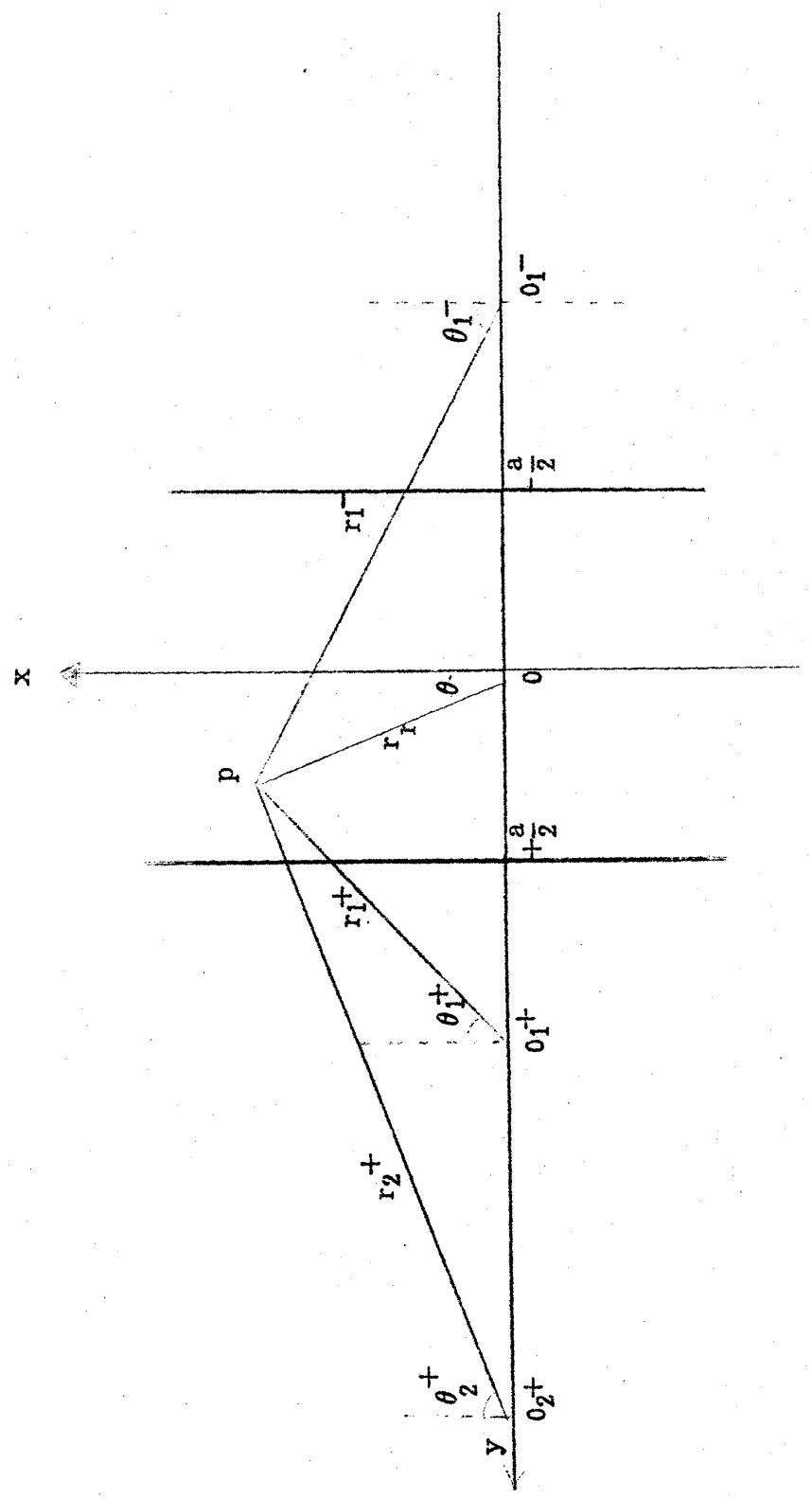


ここに、

$$
\mathcal{H}_{n}^{(2)}(\mathrm{z})=\sum_{\mathrm{p}=1}^{\infty}(-)^{\mathrm{p}} \mathrm{H}_{\mathrm{n}}^{(2)}(\mathrm{pz})
$$

であつて、一般に SchIomi I ch 級数 ${ }^{(25)}$ と言われる型のるのである。尚 (21) 式の級数は 一般に収欲度が桠めて畺い。

$$
\mathrm{H}_{n}{ }^{(2)}(\mathrm{z}) \text { は } \mathrm{z}=\pi, 3 \pi, \cdots \cdots(2 \mathrm{~s}-1) \pi, \cdots \cdots \text { の点で不連続となるような函数であるが }
$$

$\mathrm{TE}_{10}$ 型波では $\pi<\mathrm{ka}<2 \pi$ であり、従つて (21) 式を次の積分表示によつてあらわす。

$$
H_{n}(z)=\frac{1}{2 j} \int_{c} \frac{e^{2 \pi j p} H_{n}^{(2)}(p z)}{\sin p \pi} d p
$$

積分路は複素 $\mathrm{p}$ 平面内の可附番無限個の点 $\mathrm{p}=1,2,3, \cdots \cdots \cdots \cdot \cdots$ のまわりの小円に沿つて一周す るようにとつたものの和である。留数計算により、これら個々の積分值が (21) 式右辺各項に等 しいことは容易に確かめられる。(Appendix)

次に未定係数 $\mathrm{B}_{\mathrm{n}}$ を求らるには入射波電界 $\mathrm{E}_{\mathrm{A}}$,プラズマ円柱内電界 $\mathrm{EC}$, 及び散乱波電界 $\mathrm{E}_{\mathrm{B}}$ に 対し、プラズマ円柱表面上に㧤いて次の連絡条件を满足させる。

$$
\begin{array}{ll}
\mathrm{E}_{\mathrm{A}}+\mathrm{E}_{\mathrm{B}}=\mathrm{E}_{\mathrm{C}} & : \mathrm{r}=\rho \\
\frac{\partial \mathrm{E}_{\mathrm{A}}}{\partial \mathrm{r}}+\frac{\partial \mathrm{E}_{\mathrm{B}}}{\partial \mathrm{r}}=\frac{\partial \mathrm{EC}_{\mathrm{C}}}{\partial \mathrm{r}} & : \mathrm{r}=\rho
\end{array}
$$

尚入射波電界 $E_{A}$ は (15) 式及び (16) 式より

$$
\mathrm{E}_{\mathrm{A}}=\sum_{1 \mathrm{~F}=0}^{\infty} \operatorname{An} \mathrm{Jn}(\mathrm{kr}) \cos \mathrm{n} \theta
$$

散乱波電界 $\mathrm{E}_{\mathrm{B}}$ は $(20)$ 式 そのまま

$$
\begin{aligned}
& \mathrm{E}_{\mathrm{B}}=\sum_{\mathrm{n}=0}^{\infty} \sum_{\mathrm{m}=-\infty}^{\infty} \mathrm{BnH}_{\mathrm{n}}{ }^{(2)}(\mathrm{kr}) \cos \mathrm{n} \theta \\
& +2 \sum_{\mathrm{n}=0}^{\infty} \sum_{\mathrm{m}=-\infty}^{\infty} \mathrm{B}_{\mathrm{n}} \widetilde{\mathrm{H}}_{\mathrm{n}+\mathrm{m}}^{(2)} \quad(\mathrm{ka}) \mathrm{J}(\mathrm{kr}) \\
& \times \cos \frac{n-m}{2} \pi \circ \cos m \theta
\end{aligned}
$$


ブラズマ円柱内電界 $\mathrm{E}_{\mathrm{C}}$ は (14) 式より

$$
\mathrm{E}_{\mathrm{C}}=\sum_{\mathrm{n}=0}^{\infty} \mathrm{C}_{\mathrm{n}} \mathrm{G}_{\mathrm{n}}(\mathrm{r}) \cos \mathrm{n} \theta
$$

である。

これらを(23) 式に代入して $\cos \mathrm{n} \theta$ の各係数を等しいと持き、更に $\mathrm{C}$ 消去すると、次 のような $B_{n}$ に関する無限連立 1次方程式がえられる。

$$
\begin{aligned}
& \mathrm{B}_{0}+2 f_{0} \sum_{\mathrm{m}=0}^{\infty}(-)^{\mathrm{m}} \mathrm{B}_{2 \mathrm{~m}} \widetilde{\mathrm{H}}_{2 \mathrm{~m}}^{(2)}+\mathrm{A}_{0} f_{0}=0 \\
& \left.\mathrm{~B}_{2 \mathrm{n}}+2 f_{2 \mathrm{n}} \stackrel{\mathrm{m}=0}{\infty}(\rightarrow) \mathrm{n}+\mathrm{m}_{\left[\tilde{\mathrm{H}}_{2 m}+2 \mathrm{n}\right.}^{(2)}+\widetilde{\mathrm{H}}_{2 \mathrm{~m}-2 \mathrm{n}}^{(2)}\right] \mathrm{B}_{2 \mathrm{~m}}+\mathrm{A}_{2 \mathrm{n}} f_{2 \mathrm{n}}=0 \\
& : \mathrm{n}=1,2,3 \text {, } \\
& \mathrm{B}_{2 \mathrm{n}+1}+2 f_{2^{\mathrm{n}+1}} \sum_{\mathrm{m}=0}^{\infty}()^{\mathrm{n}+\mathrm{m}}\left[\widetilde{\mathrm{H}}_{2 \mathrm{n}+2 \mathrm{~m}+2}^{(2)}+\widetilde{\mathrm{H}}_{2 \mathrm{~m}-2 \mathrm{n}}^{(2)}\right] \\
& \times \mathrm{B}_{2 \mathrm{~m}+1}+\mathrm{A}_{2 \mathrm{k}+1} f_{2 \mathrm{n}+1}=0 \\
& :=0,1,2,3,
\end{aligned}
$$

ここに

$$
f_{\mathrm{n}}=\frac{\mathrm{G}_{\mathrm{n}}(\rho) \mathrm{J}_{\mathrm{n}}^{\prime}(\mathrm{k} \rho)-\mathrm{J}_{\mathrm{n}}(\mathrm{k} \rho) \mathrm{G} \mathrm{n}^{\prime}(\rho)}{\mathrm{G}_{\mathrm{n}}(\rho) \mathrm{H}_{\mathrm{n}}^{(2)}(\mathrm{k} \rho)-\mathrm{H}_{\mathrm{n}}^{(2)}(\mathrm{k} \rho) \mathrm{G}_{\mathrm{n}}^{\prime}(\rho)}
$$

（29）式のドットはrに関する微分を意味する。(26)〜 (28) 式の解は無限行列式を用いて表わ されることになる。

しかし、k

$$
f_{\mathrm{n}}(\mathrm{k} \rho) \sim 0\left[(\mathrm{k} \rho)^{2 \mathrm{n}}\right]
$$

であるから、 $f_{0}$ に対して $f_{2}$ 以下、 $f_{1}$ に対して $f_{3}$ 以下を無視して考えても十分より近似がえ られる。その場合には、 $B_{0}, B_{1}$ は (26) 式及び (28) 式から直ちに求められて、

$$
\begin{aligned}
& \mathrm{B}_{0}=\frac{-\mathrm{A}_{0} f_{0}}{1+2 f_{0} \widetilde{\mathrm{H}}_{0}(2)} \ldots \ldots . . . . \\
& \mathrm{B}_{1}=\frac{-\mathrm{A}_{1} f_{1}}{\left.1+2 f_{1} \widetilde{\mathrm{H}}_{0}(2)_{4} \widetilde{\mathrm{H}}_{2}^{(2)}\right]}
\end{aligned}
$$




\section{高山・大原・池上}

となる。

尚自由空閤においては、(20) 式右边污 2 項を考慮する必要がないから、

$$
\mathrm{Bn}_{\mathrm{n}}=-\mathrm{A}_{\mathrm{n}} f_{\mathrm{n}}
$$

となり、特に条件を附加しなくてよい。(30y 式は（30)(31) 式などで $\widetilde{\mathrm{H}}_{\mathrm{n}}(2)$ と とおいたもの に相当する。

\section{§3. 反射係数括よび透過係数の計算}

反射係数刃は透過係数を求めるには、(8)式を再びデカルト座標において表示し、デカルト座標 系での散乱波の表示を求めねばならない。波動方程式

$$
\frac{\partial^{2} E_{B}}{\partial x^{2}}+\frac{\partial^{2} E_{B}}{\partial y^{2}}+k^{2} E_{B}=0
$$

の導波管内での鲢は、散乱波がx軸に対称であるここを考虑して、一般に次のように表わされる。 (为 11 因参照)

$$
\begin{aligned}
& E_{B}(x, y)=\sum_{s=0}^{\infty} E_{S}(x) \cos \frac{2 s+1}{a} \pi y \ldots \ldots . \\
& E s(x)=\frac{2}{a} \int_{-\frac{\lambda}{2}}^{\frac{\lambda}{2}} E_{B}(x, y) \cos \frac{2 s+1}{a} \pi y d y
\end{aligned}
$$

(34)式の $E_{\mathrm{B}}(\mathrm{x}, \mathrm{y})$ に対して (20) 式の表示を適用すれば $\mathrm{E}_{\mathrm{S}}(\mathrm{x})$ が求められる。

$$
\begin{aligned}
\mathrm{E}_{\mathrm{B}} & =\sum_{\mathrm{n}=0}^{\infty} \mathrm{B}_{\mathrm{n}} \mathrm{H}_{\mathrm{n}}^{(2)}(\mathrm{kr}) \cos \theta \\
& +2 \sum_{\mathrm{n}=0}^{\infty} \sum_{\mathrm{m}=-\infty}^{\infty} \mathrm{B}_{\mathrm{n}} \widetilde{\mathrm{H}}_{\mathrm{n}+\mathrm{m}}^{(2)}(\mathrm{ka}) J_{\mathrm{m}}(\mathrm{kr}) \cos \frac{\mathrm{n}-\mathrm{m}}{2} \pi \cdot \cos m \theta
\end{aligned}
$$

ここで (19) 式の計算に用いた公式 (24)により、（20）式の r 部分をxと y で書き直す。すな わち为 1 項は

$$
\mathrm{H}_{\mathrm{n}}^{(2)}(\mathrm{kr}) \cos \mathrm{n}= \begin{cases}\sum_{=-\infty}^{\infty}(-) \ell \mathrm{H}_{\mathrm{n}+2 \ell}^{(2)}(\mathrm{kx}) \mathrm{J}_{2} \ell^{(\mathrm{ky})} & (\mathrm{x}>\mathrm{y}) \\ \sum_{\ell=-\infty}^{\infty}(-) \ell & \mathrm{J}_{2 \ell-\mathrm{n}}(\mathrm{kx}) \mathrm{H}_{2} \ell^{(2)}(\mathrm{ky})\end{cases}
$$


マイクロ波反射法によるブラズマの密度測定

また为 2 項は更に(48) 式の表示をでさかのぼつて書き直した方が都合よい。

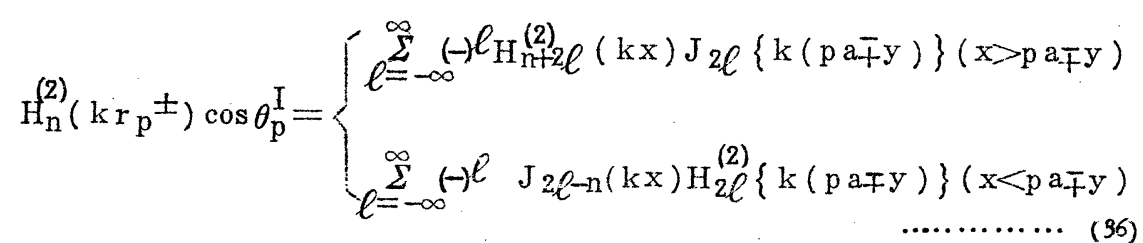

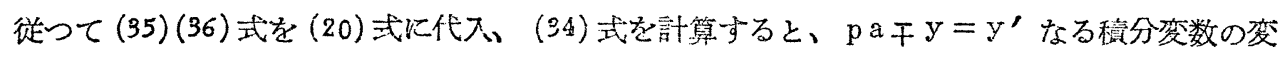
換により

$$
\begin{aligned}
& \int_{-\frac{\mathrm{a}}{2}}^{\frac{\mathrm{a}}{2}} \mathrm{Z}_{2 \ell}\{\mathrm{k}(\mathrm{pa} \mathrm{y})\} \cos \frac{2 \mathrm{~s}+1}{\mathrm{a}} \pi \mathrm{ydy} \\
& =\left(\rightarrow \mathrm{p} \int_{\left(\mathrm{p}-\frac{1}{2}\right) \mathrm{a}}^{\left(\mathrm{p}+\frac{1}{2}\right) \mathrm{a}} \mathrm{Z}_{2 \ell}\left(k \mathrm{y}^{\prime}\right) \cos \frac{2 \mathrm{~s}+1}{\mathrm{a}} \pi \mathrm{y}^{\prime} \mathrm{d} \mathrm{y}^{\prime}\right.
\end{aligned}
$$

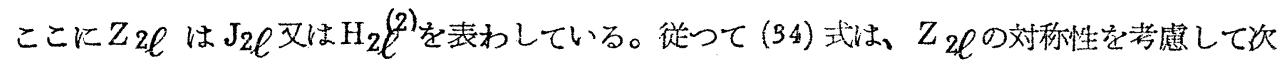
のように表わされる。

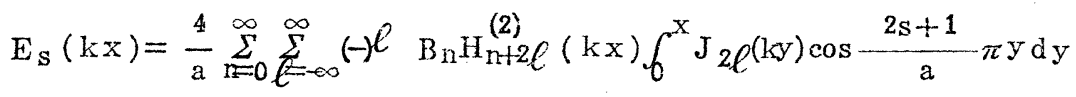

$$
\begin{aligned}
& +\frac{4}{a} \sum_{n=0}^{\infty} \sum_{\ell=\infty}^{\infty}(-) \ell B_{n} J_{2 \ell-n}(k x) \int_{x}^{\infty} H_{2 \ell}^{(2)}(k y) \cos \frac{2 s+1}{a} \pi y d y
\end{aligned}
$$

(37) 式に扔いて $\mathrm{x} \rightarrow \infty$ のときの $\mathrm{E}_{\mathrm{S}}$ が然限薣方での教乱波の椂子を表わし、透過係数又は反 射係数をあたえる。

自由空閏に尔いてに (20) 式の右边为一項そのものが散乱波の各成分を表わしている。デカルト 座標系での春示が必要な場合には(35)式を用いればよい。

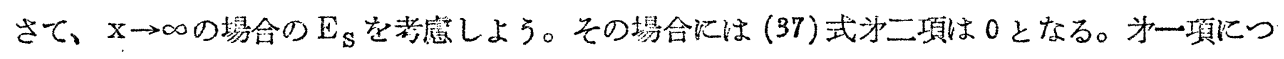
いては

$$
\int_{0}^{\infty} \mathrm{J}_{2 \ell}(\mathrm{ky}) \cos \frac{2 \mathrm{~s}+1}{a} \pi \mathrm{ydy}
$$




$$
= \begin{cases}\frac{\cos \left(2 \ell \sin ^{-1} \frac{\pi}{\mathrm{pa}}\right)}{\mathrm{k}^{2}-\left(\frac{\pi}{\mathrm{a}}\right)^{2}}=\left(-\ell \ell \frac{\cos 2 \ell \psi}{\sqrt{\mathrm{k}^{2}-\left(\frac{\pi}{\mathrm{a}}\right)^{2}}}\right. & : \mathrm{s}=0 \\ 0 & : s=1,2,3, \cdots \cdots\end{cases}
$$

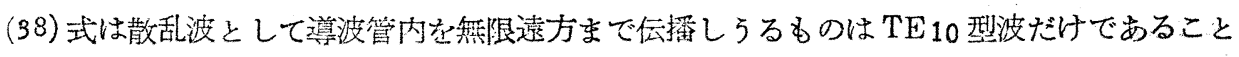
を示している。

次に

$$
\begin{aligned}
& \lim _{x \rightarrow \infty} \sum_{\ell=-\infty}^{\infty} \mathrm{H}_{\mathrm{n}+2 \ell}^{(2)}(\mathrm{kx}) \cos 2 \ell \psi \\
= & \lim _{\mathrm{x} \rightarrow \infty}\left\{\begin{array}{l}
\cos \mathrm{n} \varphi{ }_{\mathrm{m}=0}^{\infty} \in 2 \mathrm{~m}_{2 \mathrm{~m}}^{(2)}(\mathrm{kx}) \cos 2 \mathrm{~m} \psi \quad(\mathrm{n}: \text { even }) \\
\sin \mathrm{n} \varphi \sum_{m=0}^{\infty} \in 2^{\mathrm{m}+1} \mathrm{H}_{2 \mathrm{~m}+1}^{(2)}(\mathrm{kx}) \sin (2 \mathrm{~m}+1) \psi(\mathrm{n}: \mathrm{odd})
\end{array}\right.
\end{aligned}
$$

を求めよう。尚にm 快 Neumann の係数である。

HankeI 四数の積分言示

$$
\begin{aligned}
& \mathrm{H}_{2 \mathrm{~m}}^{(2)}(\mathrm{kx})=\frac{1}{\pi} \int_{0}^{\pi} \mathrm{e}^{-\mathrm{jkx} \sin \psi \cos 2 \mathrm{~m} \varphi \mathrm{d} \psi+\mathrm{j}^{\frac{2}{\pi}} \int_{\int^{\mathrm{e}}}^{\infty} \operatorname{tax} \sinh z} \cosh 2 \mathrm{~m} \mathrm{ddz} \\
& \mathrm{H}_{2 \mathrm{~m}+1}^{(2)}(\mathrm{kx})=\frac{\mathrm{j}}{\pi} \int_{0}^{\pi} \mathrm{e}^{-\mathrm{jkx} \sin \psi} \sin (2 \mathrm{~m}+1) \varphi \mathrm{d} \varphi-\mathrm{j} \frac{2}{\pi} \int_{0}^{\infty} e^{-\mathrm{kx} \sinh z} \sinh (2 \mathrm{~m}+1) z \mathrm{dz}
\end{aligned}
$$

において、夫々の为 2 項は $\mathrm{x} \rightarrow \infty$ とき0に収斂する。従つて

$$
\begin{aligned}
\stackrel{\mathrm{m}}{\Sigma}=0_{0} & \in 2 \mathrm{~m} \mathrm{H}_{2 \mathrm{~m}}^{(2)}(\mathrm{kx}) \cos 2 \mathrm{~m} \psi \\
= & \frac{1}{\pi} \int_{0}^{\pi} \mathrm{e}^{-\mathrm{j} k \mathrm{kx} \sin \psi} \sum_{\mathrm{m}=0}^{\infty} \in \mathrm{m} \cos 2 \mathrm{~m} \varphi \cos 2 \mathrm{~m} \varphi \mathrm{d} \psi \\
& =\frac{1}{2 \pi} \int_{0}^{\pi} \mathrm{e}^{-\mathrm{j} k x \sin \varphi} \sum_{\mathrm{m}=0}^{\infty} \in \mathrm{m}[\cos 2 \mathrm{~m}(\psi+\varphi)+\cos 2 \mathrm{~m}(\psi-\varphi)] \mathrm{d} \varphi
\end{aligned}
$$




$$
\begin{aligned}
& =\int_{0}^{\pi} e^{-j \mathrm{kx} \sin \varphi}[\delta(\phi+\varphi)+\delta(\psi-\varphi)] \mathrm{d} \varphi \\
& =e^{-j k x \sin \psi}
\end{aligned}
$$

(40)式は無限溒方での透過波を表るしている。尚 (40) 式の導出に抢いては次の公式 ${ }^{(26)}$ が 用いられた。

$$
\sum_{\mathrm{m}=0}^{\infty} \epsilon_{\mathrm{m}} \cos \mathrm{m} \varphi=2 \pi \delta(\varphi)
$$

全く同粎にして

$$
\begin{aligned}
& \sum_{m=0}^{\infty} \epsilon_{2 m+1}^{(2)} \cdot(k x) \text { sin }(2 m+1) \psi \\
& =j e^{-j k x} \sin \psi
\end{aligned}
$$

従つて透過波は次のように表わされる。

$$
\begin{aligned}
& \lim _{x \rightarrow+\infty} E_{0}(k x)=\frac{4}{a \sqrt{k^{2}-\left(\frac{\pi}{a}\right)^{2}}} \sum_{m=0}^{\infty}\left\{B_{2 m} \cos 2 m \psi\right. \\
& \left.+j B_{2 m+1} \sin (2 m+1) \psi\right\} e^{-j k x \sin \psi}
\end{aligned}
$$

区射波の場合 $\lim _{\mathrm{x} \rightarrow-\infty} \mathrm{E}_{\mathrm{S}}(\mathrm{x})$ については、(17)(18)式に拈いて

$$
\theta \rightarrow \pi-\theta, \quad \theta \mathrm{p}^{ \pm} \rightarrow \pi-\theta \mathrm{p}^{ \pm}
$$

の变換を行つてから、同様の計算を綠り返えせばよい。この变換は $\mathrm{B}_{\mathrm{n}}$ を( $(-)^{\mathrm{n}} \mathrm{B}_{\mathrm{n}}$ でれき かえたものに等しくなる。

以上の結果を綜合すると、

$$
\lim _{\mathrm{x} \rightarrow \pm \infty} \mathrm{E}_{\mathrm{B}}(\mathrm{x}, \mathrm{y})=\lim _{\mathrm{x} \rightarrow \pm \infty} \sum_{\mathrm{S}=0}^{\infty} \mathrm{E}_{\mathrm{S}}(\mathrm{x}) \cos \frac{2 \mathrm{~s}+1}{\mathrm{a}} \pi \mathrm{y}
$$




$$
\begin{aligned}
& \text { 高山・大原・池上 } \\
& =\frac{4}{a \sqrt{k^{2}-\left(\frac{\pi}{a}\right)^{2}}} \stackrel{\infty}{=}\left\{B_{2 m} \cos 2 m \psi \pm j B_{2 m+1} \sin (2 m+1) \psi\right\} \\
& \times e^{\mp j k x \sin \psi} \cos \frac{\pi}{a} y
\end{aligned}
$$

結局、透過波としては

$$
\operatorname{Iim}\left(E_{A}+E_{B}\right)=T_{e}-j k x \sin \varphi \cos \frac{\pi}{a} y
$$

Tは避過係数であつて

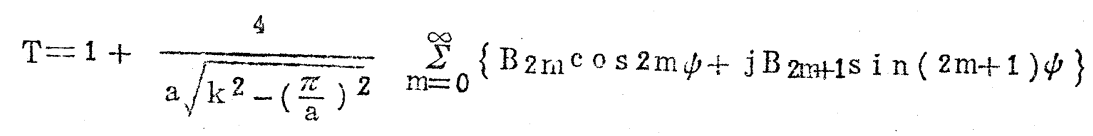

反射波は

$$
\lim _{x \rightarrow-\infty} E_{B}=R e^{j k x \sin \psi \cos \frac{\pi}{a} y}
$$

反射係数 Rは

$$
R=\frac{4}{a \sqrt{k^{2}-\left(\frac{\pi}{a}\right)^{2}}} \sum_{m=0}^{\infty}\left\{B 2 m \cos 2 m_{\psi-j B} B_{2 m+1} \sin (2 m+1) \psi\right\}
$$

$\mathrm{k} \rho \ll 1$ の近促において、 $\mathrm{Bn}$ に対して (30)(31) 式の近似式を適用、 $\mathrm{B}_{2}$ 以上の高次琪を省 略すれば、彩過係数怙よび反射係数は、

$$
\begin{aligned}
& \mathrm{T}=1-\frac{4}{\mathrm{a} \sqrt{\mathrm{k}^{2}-\left(\frac{\pi}{\mathrm{a}}\right)^{2}}}\left[\frac{f_{0}}{1+2 f_{0} \widetilde{\mathrm{H}}^{(2)}}+\frac{\mathrm{k}^{2}-\left(\frac{\pi}{\mathrm{a}}\right)^{2}}{\mathrm{k}^{2}} \frac{2 f_{1}}{1+2 f_{1}\left(\widetilde{\mathrm{H}}_{0}^{(2)}+\mathrm{H}_{2}^{(2)}\right.}\right] \\
& \mathrm{R}=-\frac{4}{\sqrt{\mathrm{a} \mathrm{k}^{2}-\left(\frac{\pi}{\mathrm{a}}\right\}}}\left[\frac{f_{0}}{1+2 f_{0} \widetilde{\mathrm{H}}_{0}^{(2)}}-\frac{\mathrm{k}^{2}-\left(\frac{\pi}{\mathrm{a}}\right)^{2}}{\mathrm{k}^{2}} \frac{2 f_{1}}{1+2 f_{1}\left(\widetilde{\mathrm{H}}_{0}^{(2)}+\mathrm{H}_{2}(2)\right.}\right]
\end{aligned}
$$


Кよつてあたえられる。

(46) 式文は (48) 式から容易にわかるように、プラズマの密穈分布(1)式を考虑したことによ る効果は、 $f_{\mathrm{n}}$ の函数にすべて含をれている。

更に $f_{\mathrm{m}}(\mathrm{kr})$ の中に怙いては

$$
\left[\mathrm{d} \ell_{\mathrm{n}} \mathrm{G}_{\mathrm{m}}(\mathrm{kr}) / \mathrm{dr}\right]_{\mathrm{r}=\rho}
$$

の形で含をれていることがわかる。

いま(1)式の密度分布を平均し、一様密密度分布に纱き代えたときの(8)式の解を $\overline{\mathrm{Gm}(\mathrm{r})}$ としよ 5。

$$
\overline{\mathrm{G}_{\mathrm{m}}(\mathrm{r})} \infty \mathrm{J}_{\mathrm{m}}\left(\sqrt{\mathrm{n}^{2}+\frac{1}{2} \alpha^{2}} \mathrm{kr}\right)
$$

$\overline{\mathrm{Gm}_{\mathrm{m}}(\mathrm{r})}$ と $\mathrm{Gm}(\omega)$ について (48) 式の值を比較してみよう。

$$
\begin{aligned}
\left.\mathrm{k}^{-1} \frac{\mathrm{d} \ln \mathrm{Go}(\mathrm{r})}{\mathrm{dr}}\right]_{\mathrm{k}=\rho}= & -\frac{1}{2}\left(\mathrm{n}^{2}+\frac{1}{2} \alpha^{2}\right) \mathrm{k} \rho-\frac{\mathrm{n}^{2}}{2^{4}}\left(\mathrm{n}^{2}+\frac{1}{3 !} \alpha^{2}\right)(\mathrm{k} \rho)^{3} \\
& +0\left\{2^{-7} \mathrm{n}^{6}(\mathrm{k} \rho)^{5}\right\} \\
\left.\mathrm{k}^{-1} \frac{\mathrm{d} \ln \overline{\mathrm{G}(\mathrm{r})}}{\mathrm{dr}}\right]_{\mathrm{r}=\rho}=- & \frac{1}{2}\left(\mathrm{n}^{2}+\frac{1}{2} \alpha^{2}\right) \mathrm{k} \rho-\frac{\mathrm{n}^{2}}{24}\left(\mathrm{n}^{2}+\alpha^{2}\right)(\mathrm{k} \rho)^{3} \\
& +0\left\{2^{-7} \mathrm{n}^{6}(\mathrm{k} \rho)^{5}\right\}
\end{aligned}
$$

この2式を比較すると

$$
\left|\mathrm{n}^{2} \mathrm{k} \rho\right| \ll 10
$$

の条件下では、推定される透過係数又は反射係数は、(1)式の分布を平均した一樣な密度分布によ

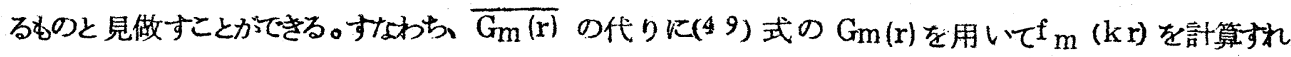
ばよい。をたとのよろな条件下では B。のみを考慮し、B1以上の高次項を省略しても十分によい結 果がえられる

一般に $(50)$ 式の条件が満足されない場合には、G(r)を用いBn の高次項までもとり入れて 複雑な計算を行なわねばならない。更に厳密には (26)〜 (28)式の連立方程式の解法にまでさか のぼつて検討を加光なければならない。 
Appendix $\mathrm{H}_{n}^{(2)}$ の計算

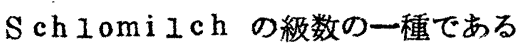

$$
\mathrm{H}_{\mathrm{n}}^{(2)}(\mathrm{z})=\Sigma\left(\rightarrow \mathrm{p}^{(2)} \quad(\mathrm{pz})\right.
$$

は極めて収斂度の悪い級数でありそのままでは値を求めることが困難であるため、（22）式の積 分法によつて更に収斂度の高い級数に書き直す。この計算はすでに後藤三男氏(19) が詳しい結 果を発言されているものであるが、その文朝は現在殆ど見ることができないかと思われるので、 こつにそのあらましを再録する。

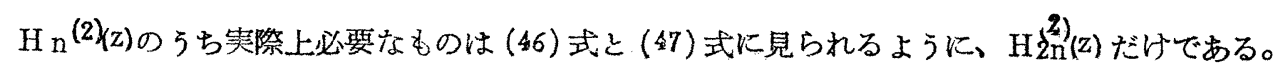
$\mathrm{Hn}^{(2)}(\mathrm{z})$ は、 $\mathrm{z}=\pi, 3 \pi, \cdots \cdots,(2 \mathrm{~s}+1) \pi, \cdots \cdots$ の点で不連続になる。

まず $\mathrm{z}$

$$
\begin{gathered}
(2 \mathrm{~s}-1) \pi<z<(2 s+1) z \\
: \quad s=0,1,2, \cdots \cdots \cdots \cdots
\end{gathered}
$$

なる筑因にある値をとるものとし、(A-1) 式を次のような積分表示にあらわす。

$$
\mathrm{H}_{2 \mathrm{n}}^{(2)}(\mathrm{z})=\frac{1}{2 j} \int_{\mathrm{c}} \frac{\mathrm{e}^{2 \mathrm{jsp} \pi \mathrm{H}_{2 \mathrm{n}}^{(2)}}(\mathrm{pz})}{\mathrm{sin} \mathrm{p \pi}} \mathrm{dp}
$$

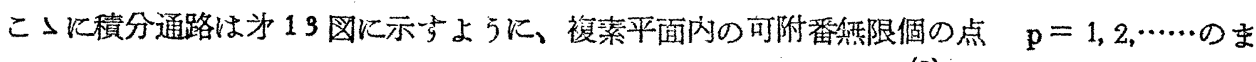
わりの小円に沿つて一周するようにとつたものの和である。また $\mathrm{H}_{2 \mathrm{n}}^{(2)}$ (Z) は多洒函数である から p 平面上に怙ける cut I ine を負の実朝上にとる。（A-3）の被積分函数はあきらか K、 $\mathrm{p}=0, \pm 1, \pm 2, \cdots \cdots \cdots$....以外特異点をもたない。

$$
\mathrm{H}_{2 \mathrm{n}}^{(2)}(\mathrm{z})=\lim _{\mathrm{R} \rightarrow \infty} \frac{1}{2} \mathrm{j}\left(\int_{\mathrm{AK}_{1} \mathrm{~B}_{1}}+\int_{\mathrm{B}_{1} \mathrm{C}}+\int_{\mathrm{CL}_{1} \mathrm{DL}_{2} \mathrm{C}}+\int_{\mathrm{CB}_{\mathrm{Z}}}+\int_{\mathrm{B}_{2} \mathrm{~K}_{2} \mathrm{~A}}\right)
$$

HankeI 函数の漸近形を用いると、半円 $\mathrm{AK}_{\mathbf{1}} \mathrm{B}_{1}$ 上では

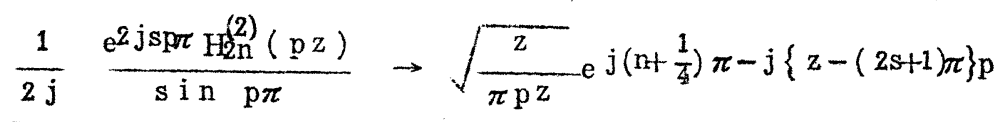

となつつ、 $\mathrm{R} \rightarrow \infty$ のさ $\mathrm{j}$ の虚数部は負の無限大となる。

従つて半円 $\mathrm{AK}_{1} \mathrm{~B}_{1}$ 上での積分情数函数的に零に议钽する。全く同椂にして半円 $\mathrm{B}_{2} \mathrm{~K}_{2} \mathrm{~A}$ 上の積分も零注収敛する。 


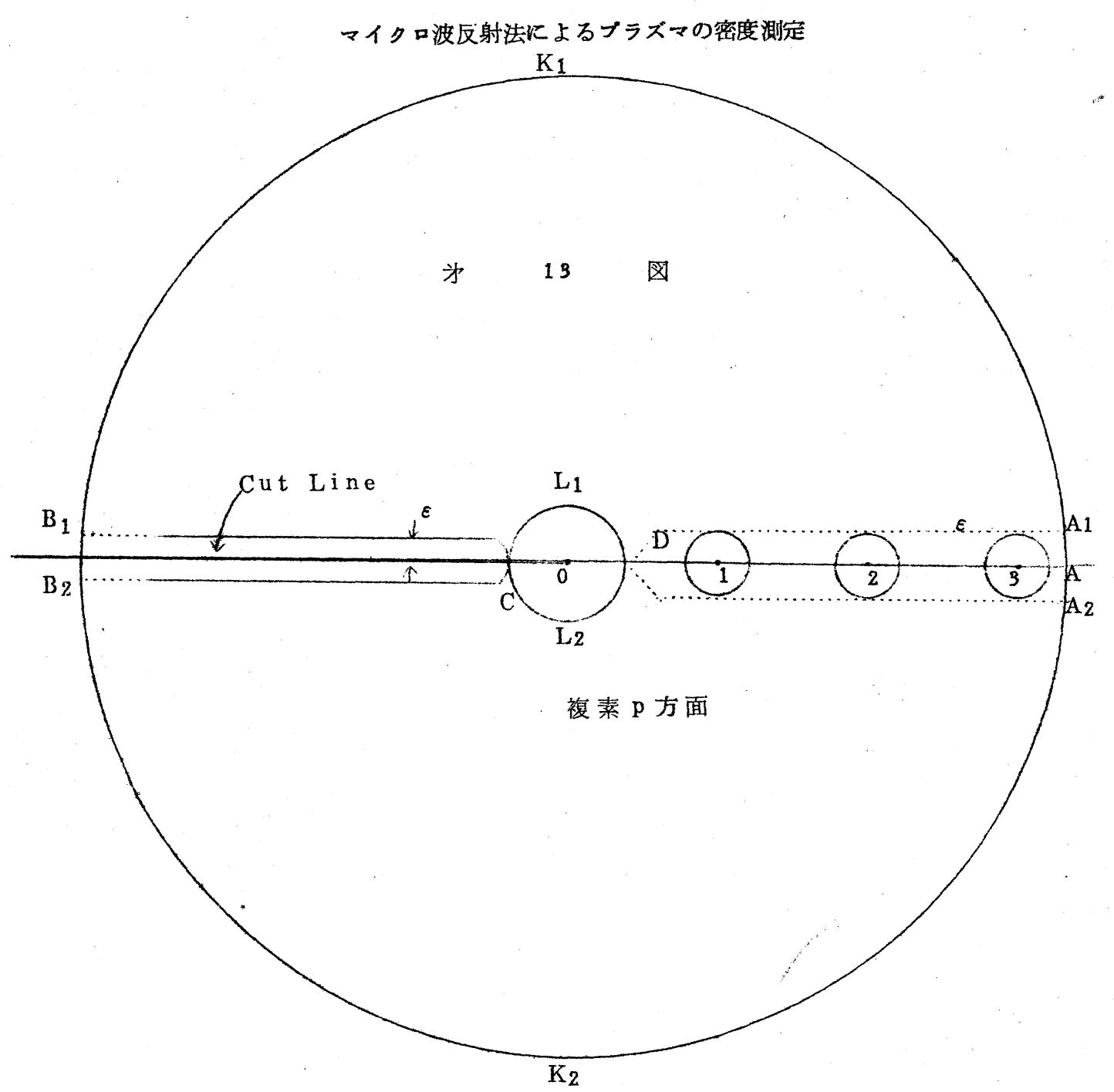

結局、 $(A-4)$ 式右辺の皟分項の为 1 項、为 5 項が省略されて

$$
\mathrm{H}_{2 \mathrm{n}}{ }^{(2)}(\mathrm{z})=\lim _{\mathrm{R} \rightarrow \infty} \frac{1}{2 \mathrm{j}}\left(\int_{\mathrm{B}_{1} \mathrm{C}}+\int_{\mathrm{CB}_{2}}+\int_{\mathrm{CL}_{1} \mathrm{DL}_{2} \mathrm{C}}\right) \cdots \cdots \cdots \cdots(\mathrm{A}-5) .
$$

次に

$$
\begin{aligned}
& \mathrm{H}_{2 \mathrm{n}}^{(2)}\left(\mathrm{ze}^{\mathrm{j} \pi}\right)=\mathrm{H}_{2 \mathrm{n}}^{(2)}(\mathrm{z})+2 \mathrm{~J}_{2 \mathrm{n}}(\mathrm{z}) \\
& \mathrm{H}_{2 \mathrm{n}}^{(2)}\left(\mathrm{ze}^{-j \pi}\right)=\mathrm{H}_{2 \mathrm{n}}^{(\mathrm{2})}(\mathrm{z})-2 \mathrm{~J}_{2 \mathrm{n}}(\mathrm{z})
\end{aligned}
$$

の変換を行い $(\mathrm{A}-5)$ 式の为 1 項及び为 2 項の積分变数をそれぞれ，p= $\mathrm{p}^{\prime} \mathrm{e} j \pi, \mathrm{p}=\mathrm{p}^{\prime} \mathrm{e}^{-\mathrm{j} \pi}$ 
とすると、

$$
\begin{aligned}
& \mathrm{H}_{2 \mathrm{n}}^{(2)}(\mathrm{z})=\lim _{\mathrm{R} \rightarrow \infty}\left\{-\frac{1}{2 \mathrm{j}} \int_{\mathrm{A}_{1} \mathrm{DA}_{2}} \frac{\mathrm{e}^{-2 \mathrm{jsp} \pi \mathrm{H}_{2 \mathrm{n}}^{(2)}(\mathrm{pz})}}{\mathrm{sin} \mathrm{p} \pi} \mathrm{dp}\right. \\
& \frac{1}{j} \int_{D_{A_{1}}} \frac{e^{-2 j s p \pi} J_{2 n}(p z)}{\sin p \pi} d p \\
& -\frac{1}{j} \int_{\mathrm{DA}_{2}} \frac{\mathrm{e}^{-2 j \mathrm{sp} \pi} \mathrm{J}_{2 \mathrm{n}}(\mathrm{pz})}{\mathrm{sin} \mathrm{p} \pi} \mathrm{dp} \\
& \left.-\frac{1}{2 j} \int_{\mathrm{CL}_{2} \mathrm{DL}_{1} \mathrm{C}} \frac{\mathrm{e}^{2 \mathrm{jsp} \pi \mathrm{H}_{2 \mathrm{n}}^{(2)}(\mathrm{pz})}}{\sin \mathrm{p} \pi} \mathrm{dp}\right\}
\end{aligned}
$$

上式の右边为 1 項は $\widetilde{H}_{2 n}^{(2)}(\mathrm{z})$ に㷌着できるから、これ忞庄辺に移項すると、結局、

$$
\begin{aligned}
& \mathrm{H}_{2 \mathrm{n}}^{(\mathrm{2})}(\mathrm{z})=\lim _{\mathrm{R} \rightarrow \infty}\left\{-\frac{1}{2 \mathrm{j}} \int_{\mathrm{DA}_{1}} \frac{\mathrm{e}^{-2 j \mathrm{sp} \pi \mathrm{J}_{2 n}(\mathrm{pz})}}{\mathrm{sin} \mathrm{p} \pi} \mathrm{dp}\right. \\
& -\frac{1}{2 j} \int_{\mathrm{DA}_{2}} \frac{\mathrm{e}^{-2 \mathrm{jsp} \pi} J_{2 n}(\mathrm{pz})}{\sin \mathrm{p} \pi} \mathrm{dp} \\
& -\frac{1}{4 j} \int_{\mathrm{CL}_{2} \mathrm{DL}_{1} \mathrm{C}} \frac{\mathrm{e}^{2 \mathrm{j} s p \pi} \mathrm{H}_{2 \mathrm{n}}^{(2)}(\mathrm{pz})}{\mathrm{sin} p \pi} \mathrm{p} \pi
\end{aligned}
$$

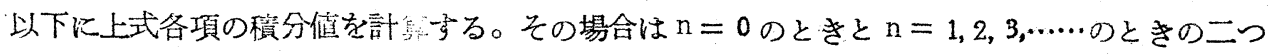
に分けて考察する。

(i) $\mathrm{n} \neq 0, \mathrm{n}=1,2,3, \cdots \cdots$ の場合

$$
\begin{aligned}
& \lim _{\substack{\mathrm{R} \rightarrow \infty \\
k \rightarrow 0}}\left(-\frac{1}{2 j} \int_{\mathrm{DA}_{1}}-\frac{1}{2 j} \int_{\mathrm{DA}_{2}}\right) \\
& =2 \int_{0}^{\infty} \mathrm{J}_{2 n}(p z) \underset{s=1}{\stackrel{s}{S}} \cos (2 \mathrm{~s}-1) \mathrm{p} \pi \mathrm{d} p \\
& +2 j \int_{0}^{\infty} J_{2 n}(p z) \underset{s=s}{\stackrel{\infty}{s}} \sin (2 s+1) p \pi d p \\
& =2 \sum_{s=0}^{s} \frac{\cos \left\{2 n \sin ^{-1} \frac{(2 s-1) \pi}{z}\right\}}{z^{2}-(2 s-1)^{2} \pi^{2}}
\end{aligned}
$$


マイクロ波反射法によるブラズマの密度測定

$$
+2 j \frac{(-)^{n}}{z^{n}}{\underset{s}{S}=s}_{s}^{\infty} \frac{\left\{(2 s+1) \pi-\sqrt{(2 s+1)^{2} \pi^{2}-z^{2}}\right\}^{2}}{\sqrt{(2 s+1)^{2} \pi^{2}-z^{2}}}
$$

$(A-8)$

次に箖分 $\int_{\mathrm{CL}_{2} \mathrm{DL}} \mathrm{C}$ を求める。これは $\mathrm{p}=0$ の近傍を案察して、

$$
\begin{aligned}
& \lim \frac{1}{4 \mathrm{j}} \int_{\mathrm{CL}_{2} \mathrm{D}_{1} \mathrm{C}}=\frac{\pi}{2} \times\left[\frac{\mathrm{e}^{2 \mathrm{j} \operatorname{sp} \pi \mathrm{H}_{2 n}^{(2)}}}{\mathrm{sin} \mathrm{pz}}\right. \text { 的関する } \\
& \text { Laurant 展開級数に括ける } \frac{1}{\mathrm{p}} \text { の係数 }
\end{aligned}
$$

なる留数計算に㷌せられる。 $\mathrm{n} \neq 0, \mathrm{n}=1,2,3, \cdots \cdots$ のとき $\mathrm{H}(2)(\mathrm{pz})$ は

$$
\begin{aligned}
& \mathrm{H}_{2 \mathrm{n}}^{(2)}(\mathrm{pz})=\frac{\mathrm{j}}{\pi \mathrm{m}=0} \sum_{0}^{\mathrm{n}}-\frac{(2 \mathrm{n}-\mathrm{m}-1) !}{\mathrm{m} !} \mathrm{dm}\left(\frac{2 \pi}{\mathrm{z}}\right)^{2 m} \\
& \mathrm{dm}=\left[\frac{\mathrm{d}^{2 \mathrm{~m}}}{\mathrm{dx} \mathrm{x}^{2 m}}\left\{\frac{\mathrm{x} \cos 25 \mathrm{x}}{\sin \mathrm{x}}\right\}\right]_{\mathrm{x}=0}
\end{aligned}
$$

$\mathrm{dm}$ m Bernoulli の数 $\mathrm{B}_{\mathrm{m}}$ を用いて次のように表わされる。

$$
\begin{aligned}
& \mathrm{dm}_{\mathrm{m}}=2\left(2^{2 \mathrm{~m}-1}-1\right) \mathrm{B}_{\mathrm{m}}+4(-)^{\mathrm{m}} \cdot \mathrm{m}\left\{1+3^{2 m-1}+5^{2 m-1}+\cdots \cdots+(2 \mathrm{~s}-1)^{2 m-1}\right\} \\
& \mathrm{d}_{0}=1
\end{aligned}
$$

最初の数個の $\mathrm{dm}$ の值は

$$
\mathrm{d}_{0}=1 \quad \mathrm{~d}_{1}=-\frac{11}{3} \quad \mathrm{~d}_{2}=\frac{127}{15} \quad \mathrm{~d}_{3}=-\frac{221}{21}
$$

であたえられる。

以上 $(A-8)(A-9)$ の結果ををとめると

$$
\begin{aligned}
\mathrm{H}_{2 \mathrm{n}}^{(2)}(\mathrm{q} \pi) & \left.=\frac{2}{\pi} \sum_{s=1}^{\mathrm{S}} \frac{\cos \left(2 \mathrm{nsin}-1 \frac{2 \mathrm{~s}-1}{q}\right.}{\sqrt{\mathrm{q}^{2}-(2 \mathrm{~s}-1)^{2}}}\right) \\
& \left.+\frac{2}{\pi} j \frac{(-)^{\mathrm{n}}}{\mathrm{q}^{2 \mathrm{n}}} \sum_{s=\mathrm{s}}^{\infty} \frac{\left\{(2 \mathrm{~s}+1)-(2 \mathrm{~s}+1)^{2}-\mathrm{q}^{2}\right\}^{2 \mathrm{n}}}{(2 \mathrm{~s}+1)^{2}-\mathrm{q}^{2}}\right)^{-\frac{1}{2 \pi}} \sum_{\mathrm{m}=0}^{\mathrm{n}} \frac{(\mathrm{n}+\mathrm{m}-1) !}{(\mathrm{n}-\mathrm{m}) !(2 \mathrm{~m}) !} \mathrm{dm}\left(\frac{2}{\mathrm{q}}\right)^{2 m}
\end{aligned}
$$

$(A-11)$ 
高山・大原 - 池上

たら゙し $\mathrm{z}=\mathrm{q} \pi \quad(2 \mathrm{~s}-1)<\mathrm{q}<(2 \mathrm{~s}+1)$ である。

(ii) $\mathrm{n}=0$ の場合

$$
\begin{aligned}
& \lim _{\substack{\mathrm{R} \rightarrow \infty \\
\mathfrak{c} \rightarrow 0}}\left(-\frac{1}{2 \mathrm{j}} \int_{\mathrm{DA}_{1}}-\frac{1}{2 \mathrm{j}} \int_{\mathrm{DA}_{2}}\right) \\
& =2 \int_{\varepsilon}^{\infty} \mathrm{J}_{0}(\mathrm{PZ}) \stackrel{\mathrm{s}}{\stackrel{\mathrm{S}}{=}} \cos (2 \mathrm{~s}-1) \mathrm{p} \pi \mathrm{dp} \\
& +2 j \int_{\epsilon}^{\infty} J_{0}(P Z) \sum_{s=s}^{\infty} \sin (2 s+1) p \pi d p \\
& =2 \sum_{s=1}^{s} \frac{1}{\sqrt{z^{2}-(2 s-1)^{2} \pi^{2}}} \\
& +2 j \sum_{s}^{\infty}\left\{\frac{1}{\sqrt{(2 s+1)^{2} \pi^{2}-z} 2^{2}}-\frac{1}{(2 s+1) \pi}\right\} \\
& +2 j \sum_{\mathrm{s}=\mathrm{s}}^{\infty} \frac{\cos (2 \mathrm{~s}+1) \varepsilon \pi}{(2 \mathrm{~s}+1) \pi}+O(\varepsilon)
\end{aligned}
$$

上式の右辺最終項は、公式 (13) そのま〉に紀さかえて

$$
\begin{aligned}
2 \mathrm{j} \Sigma(\quad) & =-\frac{\mathrm{j}}{\pi} \log \tan \frac{\varepsilon \pi}{2} \\
& -\frac{2 \mathrm{j}}{\pi} \sum_{\mathrm{s}=1}^{\infty} \frac{\cos (2 \mathrm{~s}-1) \varepsilon \pi}{2 \mathrm{~s}-1}
\end{aligned}
$$

次に $(\mathrm{A}-7)$ 式右边为 3 項は $|\mathrm{P}|=\varepsilon \ll 1$ のとき

$$
\begin{aligned}
& -\frac{1}{4 \mathrm{j}} \int_{\mathrm{CL}_{2} \mathrm{DL}_{1} \mathrm{C}}=-\frac{1}{4 \pi \mathrm{j}} \int_{\mathrm{CL}_{2} \mathrm{DL}_{1} \mathrm{C}}\left\{\frac{1}{\mathrm{p}}\left\{1-\frac{2 \mathrm{j}}{\pi}\left(1 \circ \mathrm{g} \frac{\mathrm{z}}{2}+\gamma\right)\right\}\right. \\
& \left.-\frac{2 j}{\pi} \frac{\log p}{p}+0(p \log p)\right] d p \\
& =-\frac{1}{2}\left\{1-\frac{2 j}{\pi}\left(\log \frac{\varepsilon \mathrm{z}}{2}+\gamma\right\}\right.
\end{aligned}
$$

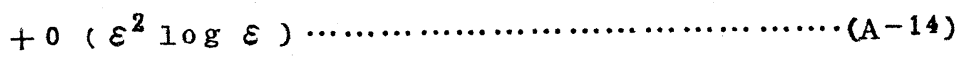

と計算される。こつに を綜合して 


$$
\begin{aligned}
& \text { マイクロ波反射法によるブラズマの密度測定 } \\
& \mathrm{H}_{0}^{(2)}(\mathrm{q} \pi)=-\frac{1}{2}+\frac{2}{\pi} \quad \mathrm{s}_{\mathrm{s}}^{\mathrm{s}} \frac{1}{\sqrt{\mathrm{q}^{2}-(2 \mathrm{~s}-1)^{2}}} \\
& -\frac{j}{\pi}\left[2 \sum_{s=1}^{s} \frac{1}{2 s-1}+\log \frac{1}{q}-r\right] \\
& +\frac{2}{\pi} \mathrm{j} \sum_{\mathrm{s}=\mathrm{s}}^{\infty}\left\{\frac{1}{\sqrt{(2 \mathrm{~s}+1)^{2}-\mathrm{q}^{2}}}-\frac{1}{2 \mathrm{~s}+1}\right\}
\end{aligned}
$$

ただし $\mathrm{z}=\mathrm{q} \pi(2 \mathrm{~s}-1)<\mathrm{q}<(2 \mathrm{~s}+1)$ とした。

以上 ( $\mathrm{A}-1$ 1 $)$ 式及び (A-15) 式とよつて $\mathrm{H}_{2 \mathrm{n}}^{(2)}$ (z) が収斂度の高い級数としてあたえられた。

\section{参考文 献}

(1) J. C. Seddon: Propagation measurements in the ionosphere with the aid of rockets, J. Geophys. Res., 58, 3P523:1953.)

(2) Owen K.Garriott: The Determination of Ionospheric

Electron Current Observations, J. Geophys, Res. 65, 4, P. 1139, P. 1151,1960

(3) James E Drummond: Theory of Micro-wave Diagnostics of Hot PIasmas, Second United Nations International Conference on the PeacafuI Uses of Atomic Energy, Geneva,p/385, USA.

(4) S. C. Brown:Microwave Studies of Gas Discharge Plasmas, Second United Nations International Conference on the Peacefull Uses of Atomic Energy, Geneva p/387, USA.

(5) K. B. Persson:Limitation of the Microwave Cavity Method in a PIasma, Phys. Rev.,106, 2, P. 191, (1957.)

(6) S. J. Buchsbaum and Sanborn C.Brown:Microwave Measurements of High Densities, Phys. Rev., 106, 2, 196, (1957.)

(7) A. C. B. LovelI and J. A. Clogg: Characteristics of Radio Echoes from Meteor Trials.Proc. Phys. Soc. (London), 460, P. 41 (1948) 


\section{高山・大原・池上}

(8) Williian S. Partiridge and L. Dole Harris: Ionization in the Trail of High-Velocity Peliets, J. Appl. Phys.,28, 11, P. $1269,(1957)$.

(9) N. Marcuritz: Waveguide Handbook, Mc. Grow-Hi II Book Company, 1951.

(10) G. J. Schulz and S. C. Brown: Microwave Study of Positive

Ion Coliection by Probes, Phys. Rev.,98, 6. P. 1642, (1955)

(11). S. Ohara and K. Takayama;

Oscillations Caused by Electron Sheath Breakdown, Rev. E. C. L. 8 1 2, 1960, P. 7

(12) 大原，高山; 昭和 35 年電気四学会連合大会 講演論交集(2) 放電㖴理 83 頁

(B) I. Longmuir, H.Mott-Smith: Phys Rev, 28729 (1926)

(44) E. O. Johnson,... L.Molter ; Phys Rev. 8058 (1950)

(15) S. A. Schelkunoff ; Quarterly of Appl. Math 178 (1943)

(19) N. Marcuvity : Waveguide Handbook, Mc graw-Hill Book Company, 1951

(ii) M,Goto : Rep.E.C.L 621.39.00101/5(04)

(8) S. C. Brown : Pape 1 "P/387 USA" presented at the Second

United Nations International Cenference on the Peaceful Uses of Atomic Energy, Geneva, Switzerland, 58.

(19) M. J. Druyoesteyn and F.M. Penning: Rev. Mod. Phys. $12.87(1940)$

(20) H.Margenau:Phys. Pev. 69 508 (1946) H.Margenau:Phys. Rev. 10906 (1958)

(21) E.A.Des loge., S.W.Mat thys se and H.Margenau: Phys.Rev.112 1437(1958)

(24) J. E. Drummond; Phys.Rev. 1121460 (1958)

(23) 小谷, 橋本: 特殊函数, (現代応用数学講座) P. 82 , 岩波書店

(24) G. N. Watson: Theory of Bessel Functions, 1922 P. 361 ,

(25). " :" P.621.

(26) P.M.Morse \& H.Feshbach :Methods of Theoretical Physics: P.1379.

(2) J.I'a Bromwich, Theory of Infinite Series, 1926 P.356(1.5)式 